\title{
Musical Mobilities
}

Son Jarocho and the

Circulation of Tradition Across Mexico and the United States

Alejandro Miranda Nieto

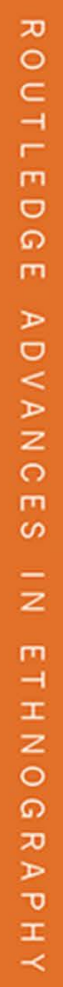

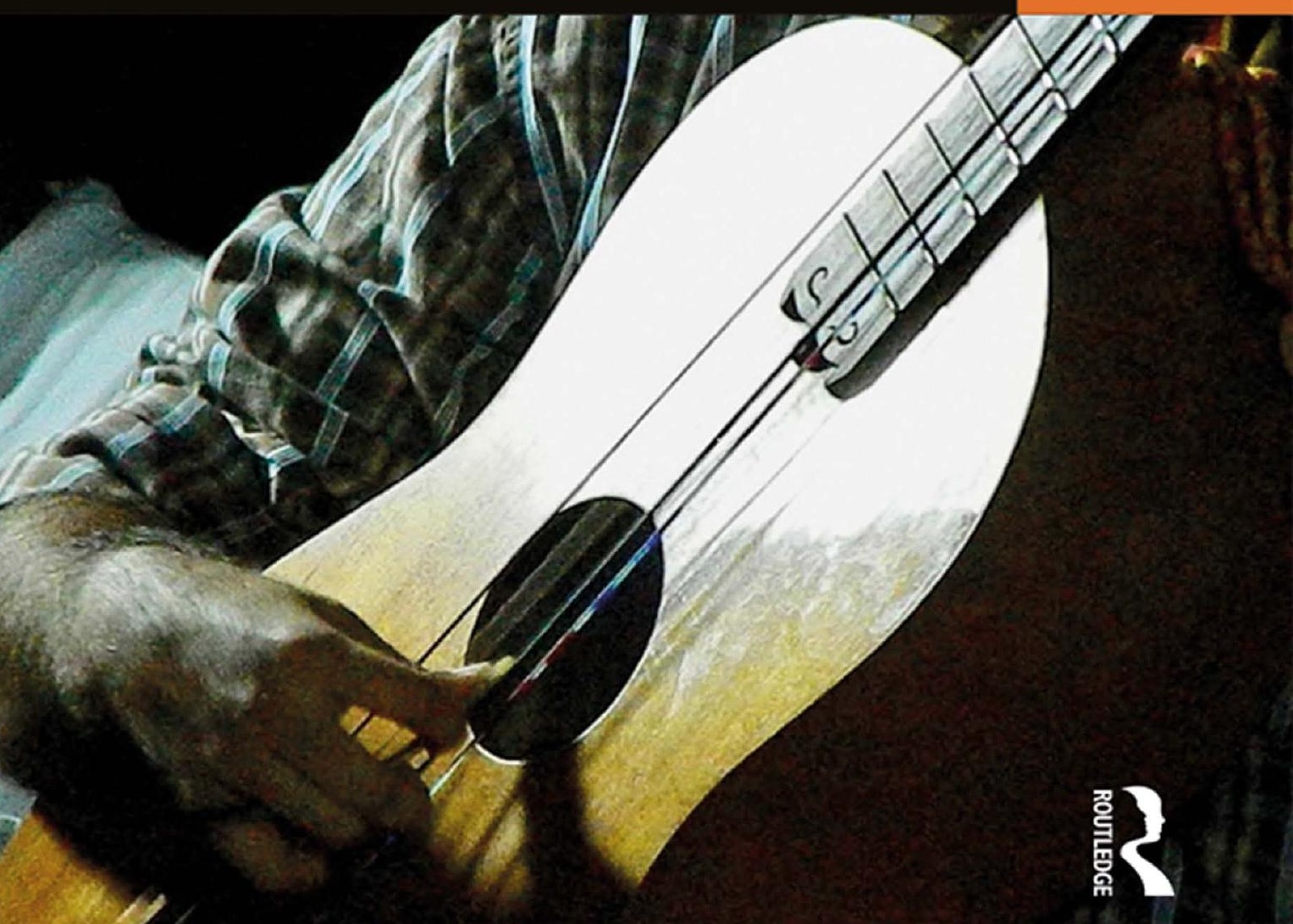




\section{Musical Mobilities}

How do musical practices move? Though technology increasingly plays a great part in establishing different degrees of spatial proximity, music making still seems to be tied to specific geographical locations, cultures or communities. The identity of musical traditions, in particular, is often demarcated by a presumed degree of uniformity among its practitioners.

Musical Mobilities analyses how a musical tradition moves literally and metaphorically: the ways in which people, objects and information travel across geographical locations, just as practices as recognisable entities circulate along with meanings, competencies and embodied dispositions. This unique ethnography focuses on son jarocho, a musical practice originating in southeast Mexico that is currently reproduced through transnational connections, particularly in the United States. Paradoxically, the transformation of son jarocho has been a noticeable outcome of its recuperation and preservation. Thus, in describing the moves of this musical tradition, this book provides a theoretical and empirical perspective on the dissonances between cultural continuity and change. The first ethnographic work to explicitly address the continuity and transformation of a musical practice through the analysis of multiple forms of mobility and fixity, Musical Mobilities will appeal to both undergraduate and postgraduate students, and to postdoctoral researchers interested in fields such as Latin American and Hispanic Studies, South American Music, Ethnomusicology, Cultural Studies and Sociology of Culture.

Alejandro Miranda Nieto is a Postdoctoral Fellow at the Department of Sociology and Social Research at the University of Trento, Italy. 


\section{Routledge Advances in Ethnography}

Edited by Dick Hobbs, University of Essex and Les Back, Goldsmiths College, University of London

Ethnography is a celebrated, if contested, research methodology that offers unprecedented access to people's intimate lives, their often hidden social worlds and the meanings they attach to these. The intensity of ethnographic fieldwork often makes considerable personal and emotional demands on the researcher, while the final product is a vivid human document with personal resonance impossible to recreate by the application of any other social science methodology. This series aims to highlight the best, most innovative ethnographic work available from both new and established scholars.

15 Young Homeless People and Urban Space

Fixed in Mobility

Emma Jackson

16 Policing the Olympics

London 2012

Gary Armstrong, Richard Giulianotti and Dick Hobbs

17 Mischief, Morality and Mobs

Essays in Honor of Geoffrey Pearson

Dick Hobbs

18 Hip Hop Versus Rap

The Politics of Droppin' Knowledge

Patrick Turner

19 Surviving Gangs, Violence and Racism in Cape Town

Ghetto Chameleons

Marie Rosenkrantz Lindegaard

20 Musical Mobilities

Son Jarocho and the Circulation of Tradition Across Mexico and the United States

Alejandro Miranda Nieto 


\section{Musical Mobilities}

Son Jarocho and the Circulation of Tradition Across Mexico and the United States

\section{Alejandro Miranda Nieto}

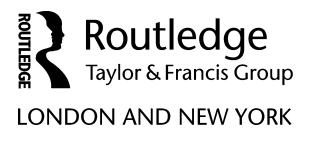


First published 2018

by Routledge

2 Park Square, Milton Park, Abingdon, Oxon OX14 4RN

and by Routledge

711 Third Avenue, New York, NY 10017

Routledge is an imprint of the Taylor \& Francis Group, an informa business

(C) 2018 Alejandro Miranda Nieto

The right of Alejandro Miranda Nieto to be identified as author of this work has been asserted by him in accordance with sections 77 and 78 of the Copyright, Designs and Patents Act 1988.

All rights reserved. No part of this book may be reprinted or reproduced or utilised in any form or by any electronic, mechanical, or other means, now known or hereafter invented, including photocopying and recording, or in any information storage or retrieval system, without permission in writing from the publishers.

Trademark notice: Product or corporate names may be trademarks or registered trademarks, and are used only for identification and explanation without intent to infringe.

British Library Cataloguing in Publication Data

A catalogue record for this book is available from the British Library

Library of Congress Cataloging in Publication Data

A catalog record for this book has been requested

ISBN: 978-1-138-71405-2 (hbk)

ISBN: 978-1-315-23115-0 (ebk)

Typeset in Times New Roman

by Taylor \& Francis Books 


\section{Contents}

List of illustrations vii

Acknowledgements viii

Introduction $\quad$ ix

1 The heartbeat of fandango 1

Tarima 1

A festivity unfolding 4

Organising fandangos 14

Interweaving movements 17

Conclusion 19

2 The historical circulation of son jarocho

Across the Atlantic 24

From Sotavento to the cities 26

Reviving a tradition 29

Beyond Sotavento 33

Conclusion 40

3 Learning at workshops

'You hardly ever hear the galloping of a horse' 42

Entering the workshop 43

Preserving a changing practice 48

Adaptation and translation 51

Critical stances towards workshops 57

Conclusion: changing as it moves 60

4 Journeying with a practice

Orchestrating movement 63

'Using whatever I had at hand' 64

The Emergence of Son Jarocho Groups 67 
vi Contents

Touring the US as a workshop facilitator 71

Conclusion 76

5 Rhythm, a manner of flowing

Repetition and process 80

(Re) configuring rhythms 83

The rhythm and metre of fandango 85

Structures of improvisation 89

Conclusion 94

6 In the grip of friction

A sense of consistency and change 98

Variegating practice 106

Essentialisms 109

Friction and traction 113

Conclusion 116

Conclusion: Practice as small world

The circulation of practice and practising 120

Spatio-temporal configurations 120

Interplay between continuity and change 121

An approach to the dynamics of mobility 122

Breaking into processual practice 124

Glossary of selected terms

Appendix

128

References

130

Index 


\section{Illustrations}

\section{Figures}

1.1 Tarima and dancers 2

1.2 Fandango unfolding 11

1.3 Musicians performing at the back of the crowd 19

$\begin{array}{ll}2.1 \text { A batch of jaranas } & 37\end{array}$

3.1 Workshop in a Sotavento town 45

3.2 In constant search of the right tuning $\quad 60$

4.1 Luthier carving out a jarana 68

5.1 Zapateado 94

6.1 Performance at a café 103

6.2 Indoor fandango in Portland 104

6.3 Outdoor fandango in San Diego 105

A.1 Map of the locations involved in this study 128

A.2 Map of the Sotavento region 129

A.3 Locations in Sotavento involved in this study 129 


\section{Acknowledgements}

This book has been possible thanks to a great deal of support. Many jaraneros have generously shared their knowledge and passion for son jarocho, turning my apprenticeship into a fascinating journey. I offer my gratitude and respect to you and the communities that cultivate fandango. I am also very grateful to Professor Dick Hobbs and Professor Les Back for their guidance and astute comments during the production of this book. Thanks also to the Routledge team for their dedication in seeing this project through.

I would like to thank Professor David Rowe and Dr Gabriela Coronado Susan for their generous critique. Their close reading and detailed feedback during my $\mathrm{PhD}$ were gifts that paved the way for this monograph. My gratitude also goes to Professor Greg Noble for his advice and support throughout my stay in Australia. His dedication and interest in this project was central for completing this book. Thank you to the Institute for Culture and Society at Western Sydney University for its generous financial support that allowed me to conduct fieldwork in multiple locations. I am also grateful to my friends and colleagues in Mexico, Australia, the US and other corners of the world who have helped me to think about and experience music making. I owe my deepest gratitude to my wife, mother, sister and many other members of my family for their advice, tolerance and love. They helped me to trust in this process and to believe that it is possible to become a cultural researcher.

Parts of Chapter 4 first appeared in an earlier form in (2016) 'Journeying with a musical practice: Existential mobility and transnational labour', in Mobile Culture Studies. The Journal 2: 15-30. This article is reproduced with permission. 


\section{Introduction}

\section{Music, circulation and performance}

People, objects and information seem to move across territories faster and further than ever before. As technical systems increasingly connect people and establish different degrees of spatial proximity, music making is partly accomplished through the mobilities of practitioners, objects, skills and meanings across locations. Yet, music making is seemingly tied to specific geographical place, culture or group of people. The identity of musical traditions, in particular, is often demarcated by its relationship with place and a presumed degree of uniformity among its practitioners. How do musical practices move? Music making, among a myriad of other cultural practices, moves literally and metaphorically: practitioners, material entities and information travel across geographical locations, just as practices as recognisable entities circulate along with meanings, competencies and embodied dispositions.

While music and other practices evidently circulate throughout social and geographical spaces, these mobilities appear unrelated to the movement produced through their enactment. Performing a given practice is a located phenomenon that unfolds as several elements become articulated and attuned with one another. The argument of this book is that to understand how practices themselves become mobile it is necessary to investigate the links between their circulation as recognisable entities and the movement produced during performances. This book examines the circulation of ways of making and experiencing music across geographically dispersed communities of practitioners. It specifically looks into the ways in which a musical tradition is enacted in different locations, and how these enactments are embedded in wider forms of circulation of a socially recognisable practice.

The empirical focus of Musical Mobilities is on son jarocho, a musical tradition that is cultivated by groups of practitioners across different locations, mostly in Mexico and the United States. It specifically looks into routines, sequences, bodily dispositions, artefacts, explicit and non-explicit rules, and ways of knowing. Far from providing an account of the 'authentic way' of performing this type of music, it develops a detailed analysis of how this practice is jointly accomplished by the spatial and temporal attunement of 
people, artefacts, tacit understandings, competencies, rules and routines. I argue that the dynamics of continuity and change of this practice emerge from the relationships among various forms of mobility - namely the movements produced during performances, the historical trajectories of son jarocho as a recognisable practice, and its dissemination through networks that extend across various locations.

There is an increasing interest of scholarly debates in questions of movement and networks (Canzler et al. 2008), as well as in speed potentials and their impact on social structures and spatial scales (Kaufmann 2002). The 'mobilities turn' has sought to redefine the notion of society by advancing a nuanced understanding of mobility and moorings to analyse contemporary social phenomena (Urry 2000). As a phenomenon and object of study, mobility is not entirely novel; after all, people, objects and information have always been on the move. Moreover, the 'new mobilities paradigm' cannot be considered as either new (Cresswell 2010: 18-19) or as a paradigm in the Kuhnian sense of the term (Kuhn 1996: 10). Yet, the novelty and value of this approach rest on its capacity to problematise the reconfiguration of practices through migration and dwelling, and to foreground questions of cultural translation as forms of mobility that have been traditionally studied by different disciplines as separate phenomena.

Human mobilities are partly constituted by practices - that is, socially established and recurrent ways of doing. Commuting to work, walking around a park, travelling as a tourist and migrating to a different city are examples of their ample repertoire. Organising, executing and recalling practices of mobility are intrinsic to everyday life. An emerging body of literature on practice has also gained a certain salience in the context of contemporary cultural theories, particularly among researchers looking for alternatives to classic approaches in the social sciences (see, for instance, Schatzki et al. 2005). Traditionally, social action has been explained in terms of instrumental interests carried out by actors or as a series of normative values shared by collectivities (Reckwitz 2002a). In contrast, the heterogeneous body of scholarship that constitutes theories of practice emphasises shared forms of doing and knowing to address both social action and structure as "embedded in collective cognitive and symbolic structures, in a "shared knowledge" which enables a socially shared way of ascribing meaning to the world' (Reckwitz 2002a: 246).

Physical displacement is intertwined with multiple forms of flow and circulation that configure and reconfigure practices. Theories of mobility and practice are two bodies of literature that have focused on cultural change in relatively independent ways, suggesting the importance of analysing the circulation, diffusion and contraction of practices (Canzler et al. 2008; Cresswell 2010; Cresswell and Merriman 2011; Shove et al. 2012). However, there is limited research focusing on how practices themselves - as recognisable entities are mobile. The work of Shove et al. (2012) on 'circuits of reproduction' and of Hui (2012; Hui 2013a; Hui 2013b) on mobile practices, networks and materials provide explicit analyses of this particular area of research. Still, the 
relationship that the circulation, expansion and contraction of practice have with the movements produced during enactments has not been explicitly developed, and requires further examination.

This book is an ethnographic exploration of a musical culture based on the analysis of multiple dynamics of mobility. Drawing from theories of social practice and mobility, it shows the relevance of analysing cultural practices in relation to their performance to discuss transnationalism, globalisation, identity and belonging. It also aims to challenge notions of musical tradition as essentially 'anchored' to a geographical place or group of people. The arguments of this study rest on the fine-grained analysis of son jarocho, a musical tradition that currently circulates across networks of relationships.

\section{Son jarocho and the expansion of a tradition}

Son jarocho is a musical practice that originated in southeast Mexico and is currently reproduced, shared and recreated in various locations in Mexico and the US. While there are numerous musical practices that also circulate across these and other countries, son jarocho is a remarkable case worthy of detailed analysis, as it is currently used by communities of practitioners to produce persuasive narratives of belonging to a localised tradition that is, nonetheless, shared and disseminated across locations. ${ }^{1}$ The tension between discourses of authenticity and belonging, and the dynamics of mobility of this practice, are a distinct feature of son jarocho.

This cultural practice emerged as a recognisable set of doings in the form of a popular festivity called fandango. At these events people get together to sing verses, play assorted instruments and dance on a wooden platform. They constitute the most representative son jarocho event in which people share and learn the practice (García de León 2009). As a product of a long gestation during colonial times, fandango became by the end of the eighteenth century the preferred celebration among the peasants and cattle drivers in the region of Sotavento in southeast Mexico. The terms sotavento and barlovento have been used for centuries by Spanish and Portuguese sailors in reference to the direction of the wind: respectively, leeward and windward. In the context of southeast Mexico, 'Sotavento' refers to the coast and plains accessed from the port of Veracruz that are protected from the sea winds. The name of this place has been elaborated from the perspective of those who arrive by ship, carrying implicit references to the colonial past and the meeting of peoples from different places. It is believed that son jarocho (which refers to the practice in general) and fandango (which refers to the specific celebration) have their background in other festive practices that came from African, European and Nahua traditions (Garcia de León 2009: 19). In any case, it is currently hard to think about Sotavento without making reference to son jarocho.

This musical tradition is distinct from other folkloric forms of music of Mexico in a number of ways. The instruments played are generically called jaranas, a term that encompasses a family of plucked instruments with five 


\section{xii Introduction}

double strings derived from the baroque guitar (see Arboleyda Castro 2004; Pareyón 2007: 532). During performances, groups of jaranas are accompanied by assorted melodic, harmonic and percussive instruments. The singing technique is usually high-pitched and has distinct melodic 'turns'. But a wooden platform on which dancers stomp to produce percussive rhythms - called a tarima - is perhaps the most significant element that distinguishes this musical tradition and furnishes it with a specific identity. The tarima constitutes the epicentre of action during performances because the music, dance and verses of son jarocho are organically articulated around this artefact.

Notable aspects of fandangos are their routines and rules which establish the organisation of sequences of actions. Practitioners share a common understanding of how to proceed, and there is a degree of predictability in the manner in which events unfold. For instance, during fandangos it is commonly assumed (but almost never explicitly stated) that the performance should be led by the most knowledgeable practitioners, who regularly stand closer to the wooden platform where the dance is performed. This spatial order allows certain practitioners to define the tunes to be played, their key and the rhythmic 'feel' (called cadencia) that structures the interaction and turns the celebration into a coherent performance. ${ }^{2}$ Throughout this book I examine the production of spatial and temporal configurations as a dynamic of movement - and analyse it in relation to other forms of circulation and flow.

The regional and transnational circulation of son jarocho constitutes another form of mobility that has been noted by a number of scholarly works. The doctoral dissertation of Daniel E. Sheehy is a relevant example of early ethnomusicological research on son jarocho. In it, he describes son jarocho's stylistic characteristics and repertoire, and in the last chapter he links this music to changes in 'socio-economic context'. This section discusses the decline and standardisation of the traditional repertoire as a consequence of 'rapid urbanization, the advent and spread of electronic media, more effective means of transportation, the professionalization of the musician, the commercialization of rural folk music, and the tremendous growth of tourism' (Sheehy 1979: 282). This brief chapter constitutes an important testimony to the rapid social transformations that have propelled the mobilities of this practice.

There is a number of works that also deal with the stylistic and historical features of son jarocho (see, for instance, Baqueiro Foster 1942; Loza 1982; Aguirre Tinoco 1983; Baudot and Méndez 1987; Delgado Calderón 1995; Delgado Calderón 1996; Delgado Calderón 1997; Delgado Calderón 2004). However, the most influential texts from a broad social sciences perspective are to be found in the works of Antonio García de León (1996, 2002, 2009, 2011), whose historical scholarship on son jarocho has become a reference point for the study of this music. Furthermore, these works reflect an enthusiasm that has its background in García de León's activities as a son jarocho practitioner. During the 1970s, he vigorously campaigned for the valorisation and preservation of this music, along with a group of enthusiasts who 
undertook various actions to keep this way of making music 'alive'. The revival of this practice, as well as its historical unfolding, is further explored in Chapter 2, which partly draws on García de León's scholarship. Also relevant to my argument on the mobilities of son jarocho are the texts by Ricardo Pérez Montfort (1999, 2007, 2017; Ávila et al. 2011) on the cultural life in southeast Mexico and the Caribbean, and the circulation of fandango.

In recent decades, scholarly work on son jarocho has seen modest yet consistent development. There are accessible introductions to the basic elements of this music (Vázquez Domínguez 1991; Rodríguez León 1998; Figueroa Hernández 2007) and a number of texts dealing with the history of the style and repertoire of this musical tradition (Barahona Lodoño 1997; Barahona Lodoño 2013; Moreno Nájera 2009; Moreno Nájera 2013), as well as its more recent transformations (Pérez Montfort 1992; Kohl 2007; Alcántara López 2010; Vega Deloya 2011; Figueroa Hernández 2014; Macías Sánchez 2016). In the US, son jarocho has attracted the attention of some scholars, probably owing to the fact that it has become culturally visible - particularly in urban centres (see, for instance, Loza 1992; Viesca 2004; Hernández Palacio and Obrador Cuesta 2011; Balcomb 2012; Bartra 2017). A pertinent example comes from the discussion that Steven Loza develops regarding the politics of identity in Los Angeles. In this article, Loza (1992: 192) examines the 'stylistic adaptation' of son jarocho and the 'development and maintenance of syncretic musical forms' by Chicano musicians. ${ }^{3}$

Overall, the literature on son jarocho produced in either Spanish or English has tended to address this way of making music as a 'Mexican musical genre', with some authors focusing on its internationalisation. My contention is that this presumption leaves unquestioned what is 'Mexican' about it; how the presumed 'Mexican-ness' is invoked by its practitioners; and, more generally, how the very act of performing son jarocho intersects with the wider dialectics of social and cultural continuity and change. This book therefore examines how these meanings are constructed in practice, and shows that son jarocho is currently shared, reproduced and recreated through multiple dynamics of mobility.

Various authors have suggested that this musical practice has played a major role in the affirmation of local identities in Sotavento and beyond (Camastra 2006; Cardona 2006, 2011; Kohl 2007; Bartra 2017). These forms of belonging have been constructed in relation to narratives of a tradition that it is claimed needs to be valued and preserved. Paradoxically, the meanings associated with the preservation and permanence of a cultural tradition have been crucial to their mobilities, as the diffusion of the practice has been considered essential in order to keep it 'alive'. Narratives of fixity are intrinsic to the dissemination of this practice. Currently, son jarocho is re-enacted in locations as dissimilar as Mexico City, Xalapa, Veracruz, Ciudad Juarez, San Diego, Los Angeles, Seattle, New York, Chicago and Paris. Two examples of this expansion are the Fandango Fronterizo, which is a gathering of son jarocho musicians at the Tijuana and San Diego border that has been celebrated 
annually since 2008. A second example is the Encuentro de Jaraneros de California in Los Angeles and the Encuentro de Jaraneros de Tlacotalpan, festivals celebrated respectively in the United States and Mexico. Son jarocho today is not exclusively associated with bounded communities of practitioners, but with numerous groups of people in different localities.

Practitioners across geographically dispersed locations have used son jarocho to elaborate discourses of valorisation and preservation of a musical heritage. The peculiarity of this musical practice (and in which sense it differs from other musical forms practised in and across Mexico and the US) resides in the manner that some practitioners explicitly describe it as a grass-roots movement of practitioners known as Movimiento Jaranero (Movement of Jarana Players). Although the so-called 'movement' does not have explicit political connotations or agendas, it aims to foster this musical practice in the context of social change that presumably threatens its existence. This point encapsulates another paradox of contemporary son jarocho: the circulation and expansion of this practice have borne its transformation, and the efforts to preserve it have entailed its inexorable change. To break into this paradoxical condition I have found it necessary to highlight the processual character of musical practice.

\section{Music as mobile practice}

To explore how this musical practice is reproduced, informed and recreated by multiple dynamics of mobility is a departure from conventional ways of thinking about music and the social. Instead of framing this phenomenon as folkloric musical genre or style, this book approaches music making as a practice. This choice has multiple consequences for the conceptualisation of what music and dance are, and for the methodological strategies to study them. Despite being one of the most prominent approaches in the study of music, analysing 'works of art' has been criticised for overlooking the sociocultural contexts in which those works emerge (see, for instance, Zolberg 1990). Sociological stances, on the other hand, have emphasised the social dimensions of musical phenomena. Since Theodor Adorno (1976) established a programme for the sociological study of music, this approach has predominantly aimed to unveil the social forces that are behind the production, consumption or distribution of music. Both perspectives (analysing works of art or interpreting the social in music) have advanced the understanding of different facets of this complex phenomenon. However, both approaches have paid little attention to the processes by which music and other related cultural practices are used to compose the social 'in action'.

The study of music as social process offers an alternative entry point for understanding how music informs the social - and vice versa. As Tia DeNora (2004: 38) succinctly puts it: 'We need, in short, to follow actors in and across situations as they draw music into (and draw on music as) social practice.' The importance of analysing musical practices does not reside in showing 
how they reflect institutions, economic conditions, people, groups, ethnicities or societies, but in understanding how music is collectively accomplished. Conceptualising music as practice makes it possible to frame this phenomenon not as a 'given thing' (namely, groups of musicians, repertoire, forms of distribution and consumption), but as a process. This is not to say that this perspective should gloss over the aforementioned elements; in fact, overlooking 'music's specifically musical materials' has been one of the flaws of societal accounts of music (DeNora 2004: 37).

Several scholarly works have addressed the relationship between mobility and music. For instance, Kiwan and Meinhof (2011) examine how migrant musicians in Africa and Europe make music as part of transnational and regional networks. Their perspective challenges conventional approaches on diasporas, migration and music by showing how contemporary music making is sometimes built upon mutual support and exchange across locations. This and other works constitute a growing field of research that show the significance of analysing different practices of mobility (like travelling, walking or migrating) in relation to music (see, for example, Connell and Gibson, 2003; Lashua and Cohen 2010; Levi and Scheding 2010; Toynbee and Dueck 2011; Born 2013; Peters 2016).

In this book I seek to contribute to this research area by advancing the analysis of performances in relation to the circulation of a recognisable practice. This strategy is based on recent theorisations of social practice (Schatzki 1996; Shove et al. 2012). More specifically, I elaborate on Schatzki's analytical distinction between practice as a performance enacted in a specific time and space and practice as 'temporally unfolding and spatially dispersed nexus of doings and saying' (1996: 89-90). The differentiation between entities and performances has been further developed by Shove et al. (2012) through the notions of practice-as-performance and practice-as-entity. Enacting a practice is produced by the articulation of elements in specific time and space. The collection of multiple, recurrent enactments in times and spaces forms practice-entities - that is, coherent and recognisable activities. Here it is important to note that the differentiation between practice-performance and practiceentity is an analytical distinction that is intended to reduce complexity. However, these two categories refer to facets of the same phenomenon and have a reciprocal and co-constitutive relationship. In the case of musical practices, this analytical contrast can be translated into the relationship between practising music (the unfolding of a given performance) and musical practice (the set of complex activities that constitute a recognisable practice). I have used this strategy to differentiate between the dynamics of movement that take place during performances and the circulation of a practice across networks of relationships.

This approach constitutes an alternative to the opposition between music as 'works of art' and their constituents (melody, harmony, counterpoint, rhythm, musical instruments, repertoire) versus music as a reflection of societal structures (such as class, gender or ethnicity). I rather highlight the transient 
character of music making. At performances there are normally several musicians, an audience, a space in which the performance takes place, musical instruments and assorted artefacts, a repertoire, and common understandings between the audience and the musicians. A multitude of different elements come together, and only then does music 'happen'. Indeed, Antoine Hennion (2001: 2) argues that: 'Music cannot be reduced to the factors that might cause it and circumscribe it, it should be seen as something transitory, not as a given but as a "new arrival", a relatively irreducible present: it happens, it passes.' In analysing the multiple ways in which various elements are assembled and articulated to set a practice in motion, I seek to move away from the dichotomy between the study of works or social factors, and to propose a processual analysis of musical mobilities. This perspective resonates with John Law's (1992: 389) suggestion that the social 'is better treated as a verb than as a noun'.

The analysis of the mobilities of son jarocho is based on ethnographic fieldwork conducted in various locations in Mexico and the US. My strategy was to pursue the spaces in which the practice of son jarocho is enacted. I found myself taking part in popular celebrations and workshops in which son jarocho is learnt, as well as in rehearsals and performances. Similarly, I spent time travelling with practitioners, busking with them at markets or listening to son jarocho recordings and streamed YouTube videos in their living rooms. As I was 'hanging out' with practitioners I gradually became involved in entangled networks of practitioners and moved from place to place as opportunities emerged.

Because my engagement with the field was through the making of son jarocho, my participation was markedly embodied and collaborative. Making music normally takes place within groups of individuals who adjust their actions to create more or less 'harmonic' interactions. For this reason, my immersion in the musical culture of son jarocho involved the adjustment of my subjective rhythms to those of the collectivity. Here I am not only referring to the rhythms played during performances: as a researcher and practitioner I had to align my patterns and particular manner of moving, eating, sleeping or drinking. Given that music making is irremediably accomplished jointly (DeNora 2004), my participation was a process of embodied learning and, at the same time, part of a series of collective improvisations that I describe in what follows.

\section{Mobility as method}

In the last book that Henri Lefebvre wrote, he puts forward the study of the rhythms of the social. One of its sections points out that 'to grasp a rhythm it is necessary to have been grasped by it; one must let oneself go, give oneself over, abandon oneself to its duration. Like in music and the learning of a language' (Lefebvre 2004: 27). In capturing the mobilities of practice I became captured by them; accessing communities of practitioners and moving 
among them rested on the act of engaging in the same rhythms as other participants. The ethnographic research upon which this book is based was to an extent circumstantial and fortuitous, and I was fortunate to encounter a series of favourable conditions that facilitated my access to communities of practitioners. I conducted fieldwork over the course of 2013 in locations in the US and Mexico, focusing on the technique of 'following the practice'. I used this phrase to remind myself that, first, I was there to pursue the points in which the practice of son jarocho was enacted, and that only then was I there to learn how to play, dance and sing. But the learning of the crafts of conducting fieldwork and making son jarocho became quickly entangled.

I actively participated in workshops, assorted festivities, informal gatherings, rehearsals, gigs and busking performances. I travelled to these events by bus, car, foot, bicycle, aeroplane, truck and boat; often with other practitioners, sometimes by myself. Following the moves of son jarocho practitioners during performances, travels and various quotidian activities became an empirical access point for studying the processes through which this practice is re-enacted in different locations. Moving with the practice allowed me to understand how human travelling is reciprocally linked to other flows, such as the circulation of a recognisable practice, its musical instruments and the reproduction of practice-specific knowledge in different contexts.

My first point of arrival was Los Angeles, and then I travelled to Mexico City and to various locations in the south and outlying areas in Veracruz. ${ }^{4}$ The objective of conducting fieldwork in geographically dispersed locations was to 'chase' fandangos, workshops and other son jarocho events as they took place. Prior to these travels, I collected dispersed pieces of information on the Internet that gave me a rough idea of the time and place of major festivities. However, this provisional calendar proved to be of little use as my trajectory took on a life on its own. After completing several months in Mexico I had a brief pause to attend a conference in Canada. Some days later I re-entered the US on a bus to continue with my fieldwork in Seattle. I spent time with practitioners in that city and other locations in Washington State, then visited various places in Oregon and, finally, California. The length of my stay in each location varied significantly. However, being based in one location always involved travelling to its surrounding areas, as communities of practitioners are densely interconnected. During the last months of my fieldwork, for instance, I based myself in Los Angeles, but continued travelling between Boyle Heights (a neighbourhood in the east of that city), the metropolitan area of Los Angeles, Santa Ana and San Diego.

My immersion in these communities was facilitated by the tendency among son jarocho practitioners to welcome strangers who show interest in this tradition. It is very common to host and be hosted after fandangos, as long-distance travelling is often required to attend these events. In my case this custom was generously extended as I often stayed at the place of practitioners for longer than the duration of the celebration. As a practitioner from southeast Mexico pointed out in one of our conversations: 
Sometimes people call me to spend the night at my house. I've been called by people who come from the US who I don't know, and they say 'Marco, you are Marco right, well a friend gave me your phone number and said that if I was in this city, I could call you because, well, I'm looking for a place to spend the night.' And that's it, they are hosted [at his place] because they are friends of friends. One is not obliged to do it, but others have also done it for me when I'm away.

Reciprocity is expected and valued among son jarocho practitioners because it is a basic mechanism that enables the formation of tight networks of relationships. This is why hosting and being hosted is an integral component of the transnational, regional and local linkages among communities of practitioners. This custom worked in my favour, as being hosted opened up the possibility of following practitioners not only while making music, but also in the quotidian aspects of their lives. It was during these periods of intense interaction that I easily forgot about being an ethnographer and became involved in the rhythms of the everyday life of son jarocho practitioners. As Goffman (1989: 129) puts it, I engaged 'in the same body rhythms, rate of movement, tapping of the feet, that sort of thing', as the surrounding people. This type of participation put me into ambivalent situations as simultaneously an outsider and an insider.

\section{Ambivalent positionality}

Several issues on my shifting positionality were raised because of the mobility implied in this type of fieldwork. Responding to the question of whether or not to be part of the social world one is to study is not straightforwardly answered in this case. As a consequence, participants categorised me in various ways depending on the context. The fact that I was born and grew up in Mexico City has certainly influenced how I conducted myself in the field and how participants categorised me. I received innumerable gestures of hospitality and amity in many locations (and also those of dismissal and disregard), possibly owing to certain identifications such as being a musician, male, Mexican or a temporary resident in Australia.

There are also significant cultural and linguistic differences across the regions in Mexico that affected the way in which my fieldwork was conducted. In southeast Mexico, for instance, my accent and appearance were not the only markers of my outsider-ness: being incapable of clearly differentiating between traditional tunes, singing verses quietly or being shy when dancing on the tarima demarcated an even clearer difference. Yet, participants saw me as an outsider willing to learn and in need of guidance, and I tried to act accordingly; but in the US it was different. There I was categorised as Mexican, and that sometimes brought me closer to a tradition thought also to be Mexican. On one occasion, for example, I attended a small son jarocho performance that took place as part of the celebrations of the foundation of a suburban 
neighbourhood of Los Angeles, California. People were leisurely walking, having coffee and enjoying a pleasantly warm evening. On the pavement, in front of a café, were three musicians playing son jarocho; on the other side of the street was a pub with a rock trio, also playing outdoors. It was an unfair volume competition as the son jarocho players were using only acoustic instruments and the other band had amplifiers. Still, the evening unfolded successfully, and on my side of the street the audience seemed to enjoy the unintended mixture of tunes from southeast Mexico spiced with modern rock beats. After the gig finished I spent some time talking to one of the son jarocho musicians, who then categorised me in a surprising way:

Guys like you, I mean, urban Mexicans are very much like us. When I was a kid, my idea of Mexicans came from what I saw when I visited my family in Zacatecas, people from the countryside, many are peasants who come here [to the US] to work. But then I met Mexicans from the cities and I just saw how much we are alike. You guys are just like Chicanos!

The multiple ways in which practitioners categorised me as a researcher and son jarocho apprentice had a direct influence on the ways in which I engaged in the field. This reciprocal relationship reveals, among other things, the collaborative nature of ethnography: difference and similarity are continuously demarcated and erased by both researcher and participants. My role as researcher was always overt, but asserting my status as an ethnographer based in Australia did not mean much to many people I met. After all, being a cultural sociologist is only one among many potential ways of presenting myself and being represented by others in the field. I had to develop a particular sensitivity to the ways in which people categorised me and to act in accord with their ascriptions. Just as musicians attune themselves to the pitch and rhythmic changes that emerge as performances unfold, so I moved across locations and had to react quickly as the context shifted. In southeast Mexico some people called me 'professor' because of my academic background, or chilango because I was born in Mexico City, whereas in California people called me 'mate' because I was based in Sydney. Moreover, being nicknamed became a marker of the degree of my involvement in each scene that was always welcomed with a smile of complicity.

In any case, my status as insider or outsider was never clearly defined. This research was not conducted by an ex-son jarocho musician going back to study his musician fellows. I was foreign to the explicit and non-explicit rules and understandings that permeate this musical tradition. Before embarking on this research project, my contact with it was primarily through cassettes, CDs and performances at folk festivals offering a commercialised form of son jarocho (addressed in Chapters 2 and 3). Mexico is a country of regionalisms (Simpson 1977) and this practice is commonly identified as music from Veracruz, which is not the region in which I grew up. Although I was unfamiliar with its actual making, I have been attracted to it for a long time. This interest 
partly stems from my training in classical music and the fact that I have been performing popular music as a professional guitarist for several years. Because of my formal musical training, this study confronted me with the blurred lines between being an outsider who is trying to understand how people construct their own culturally contained ways of doing and an insider who also makes music, speaks the same language and has similar cultural references.

In becoming a son jarocho apprentice I was confronted with many of my personal and professional prejudices. It took me some time, for instance, to understand that playing in major and minor tonalities at the same time is not inherently wrong, but a matter of choice and taste. While my previous experiences as a musician gave me a lot of confidence when playing the son jarocho instruments, this self-assurance was deflated when I was asked to dance or sing verses, which are also essential parts of the performance. Becoming an apprentice involved learning to negotiate the enactment of this practice with others, and led me to find my way in the field through singing, playing instruments and dancing. A crucial aspect of this negotiation was acknowledging my incompetence despite already being a competent musician. Understanding came through suspending my own opinions about music making.

This naive attitude stretched as I moved across different locations. In this journeying I encountered local ways of enacting the practice that involved both reproduction and transformation of the traditional ways of making son jarocho. This musical tradition is currently sustained as a recognisable practice because of the complex dynamics between continuity and change produced among groups of practitioners. Despite being shared across transnational networks of relationships, this practice constitutes a culturally contained world produced by communities of practitioners interlinked by enthusiasm for a common way of making music. The fact that these networks extend across geographically dispersed locations does not contradict the fact that they constitute a small world. Just as a single road in a cosmopolitan city can contain a broad spectrum of local worlds (Hall 2012), a relatively consistent practice can be shared across transnational social spaces. The chapters of this book seek to capture the tight bonds that currently produce the mobilities of this dispersed practice.

\section{Outline of the book}

From the study of the various dynamics of musical mobility, three interrelated themes extend throughout the book: the production of spatio-temporal configurations during performances; the circulation of musical practice (as entity) and practising (as enactment); and the interplay between cultural continuity and change. The progression of the chapters that follow elaborates different facets of these themes and their relationships. Chapter 1 focuses on practiceperformance by examining the movements that take place during enactments. Fandango, the celebration during which son jarocho is performed, is analysed as a constant motion that produces spatio-temporal configurations. It is then 
detailed how the spatial positioning and synchronisation of actions put practices in motion. The attunement of bodily gestures, tacit understandings, artefacts and meanings show how the movement that emerges during performances is constitutive of, and reciprocally related to, the circulation of this practice.

Chapter 2, in turn, addresses the circulation and dissemination of son jarocho as a recognisable entity. It briefly outlines the historical movements of this practice, based on recent studies that document the interrelation of shared ways of making music across the main ports of the Caribbean and other regions in Europe and the Americas (García de León 2002; Ávila et al. 2011). I argue that a long process of circulation of cultural practices defined many of the constitutive elements of what is currently understood as son jarocho. The chapter goes on to analyse a series of significant transformations that led this practice to its apparent disappearance and then to its recuperation by groups of enthusiasts. The efforts to valorise and preserve son jarocho have had a special resonance since the last decades of the twentieth century, especially in cities in the US. While it would be facile to attribute this expansion to the consolidated migratory system between Mexico and the US, the current circulation of this musical tradition is not a form of long-distance regionalism. Rather, these mobilities have been facilitated by: the closely imbricated networks of practitioners that have emerged around the 'rescuing' of this tradition; the work of several cultural and political organisations; a distinct 'do-it-yourself' ethos that distinguishes son jarocho from other musical practices; and its accessibility and recruitment methods.

One of the most relevant initiatives involved in the rescuing of traditional son jarocho has been the diffusion of this practice through workshops in which people learn to play instruments, dance and sing verses. Chapter 3 discusses how this practice is reproduced, shared and recreated in Mexico and the US through the adaptation and translation of practice-specific knowledge that takes place at workshops. Chapter 4 focuses on the mobilities of people. More specifically, it analyses how a practitioner travels with this practice and its significance for earning an income in a precarious context, the development of transnational communities of practitioners, and the excitement of going somewhere in life.

It has been suggested that studies of mobility have emphasised its spatial dimension while glossing over its temporalities and social rhythms (Kaufmann 2002: 22). Chapter 5 advances the notion of rhythm as a metaphor to assist the analysis of multiple dynamics of mobility. Originally derived from the Greek rhuthmos (which in turn comes from rhein, 'to flow'), the notion of rhythm refers to processes of becoming, flowing - and possibly to the 'periodic motion of waves' (Hasty 1997: 10). The discussion in this chapter draws on the notion of rhythmanalysis proposed by Henri Lefebvre (2004) and studies that elaborate on it (Edensor 2010; Schatzki 2010b; Cresswell and Merriman 2011; Fen 2012). Rhythm is used as a heuristic to connect bodily movements during performances to the mobilities of son jarocho as a recognisable entity.

While conducting the fieldwork I was constantly confronted by the stark contrast between narratives of authenticity and belonging to an essentialised 


\section{xxii Introduction}

tradition and the various forms of circulation, flow, displacement and movement in which one becomes involved as a son jarocho practitioner. Chapter 6 provides a critical reflection on this tension to examine how the contexts of enactment of this practice become places of friction and convergence. If, as Stuart Hall (1996: 4) reminds us, identities are about 'the process of becoming rather than being', then there is much to be learnt from analysing how mobile practices provide resources for the creation and negotiation of meanings. This chapter examines how the friction between essentialised discourses and the circulation of elements provides the grip that enables musical mobilities. Taken together, Chapters 5 and 6 seek to position the empirical discussion and conceptualisation of musical mobilities in relation to their temporalities and spatialities.

Overall, this book investigates different facets of the mobilities of a musical tradition to put forward a nuanced understanding of the interplay between cultural continuity and change. Throughout, music is used as a case to discuss the dynamics of culture and the social. Still, this study has been strongly influenced by the idea that music 'is good to think with' (DeNora 2003: 173). The collective and transient qualities of music make it an empirical window onto larger social processes.

So there is more to Musical Mobilities than description of son jarocho in relation to theories of practice and mobilities. In his discussion of ethnographic validity, Roger Sanjek (1990: 411) recalls the maxim that the jazz trumpeter Miles Davis used to relate to his band members: 'You need to know your horn, know the chords, know all the tunes. Then you forget about all that, and just play.' Sanjek makes this point to highlight the fact that knowing the literature, understanding the concepts and being acquainted with the fieldwork methods are fundamental to the practice of ethnography, or of any other form of empirical research. However, Sanjek continues, 'they do not produce ethnography. Like jazz, ethnography requires the person who improvises the performance, who not only knows how to do it but does it' (1990: 411). I have produced this book through my personal improvisation, both as an apprentice of the craft of cultural research and of son jarocho. The following chapters reflect such improvisation as they provide an account of musical mobilities. The next specifically analyses fandango, a popular celebration in which the synchronised articulation of elements works to keep this tradition 'on the boil'.

\section{Notes}

1 For cases between Mexico and the US see, for instance, Madrid (2011).

2 Cadencia refers to rhythmic 'feel' and should not be confused with the English term 'cadence', which describes a modulation of the voice or, in music, a sequence of chords that close a musical phrase. Cadencia can be translated in this context as swing or groove.

3 'Chicano' is a term used in the United States by some people of Mexican origin or descent to refer to their own ethnic identity.

4 See the maps provided in the Appendix. 


\section{The heartbeat of fandango}

Son jarocho practitioners understand the craft of making music beyond the mere production of organised sounds. Their performances are essentially integrated by dancing, singing verses and playing specific musical instruments. As any other form of music making, these performances can be framed as spatio-temporal sets of actions. Son jarocho dance, verse and instrument playing are articulated at the traditional celebration of the region of Sotavento called fandango. ${ }^{1}$ The term fandango has been widely used in the Americas and the Iberian Peninsula since colonial times to designate various types of dance and music. Throughout this book fandango refers to the popular celebration in which son jarocho is practised. This use of the term has been traced to the eighteenth century in archives of the Inquisition in New Spain that portray a mulato (a man of mixed ancestry) who sang verses, depicting him as 'very fandanguero' (Pérez Montfort 2003: 39, my translation; see also Delgado Calderón 2004). The adjective fandanguero was used in the context of an accusation of invoking demons through music and dance. The demonization of fandango gradually faded as it became consolidated as a popular celebration, but this practice has historically carried with it meanings that oscillate between the sacred and the profane (García de León 2009: 18). There is a ritualistic attitude towards this way of making music that takes the form of a collective belief in the practice, a compliance with the process through which this performance unfolds.

Fandango is a celebration in which the manipulation of artefacts produces various forms of embodied and collective engagement. In the following sections I focus on the motion that takes place as performances unfold. My aim is to illustrate how these ways of enacting a musical practice produce specific spatial and temporal dynamics that stem from continuous movement during performances. To give an account of these processes it is necessary to examine how musicians, dancers, instruments, verses, dance steps and other instances are in motion during performances. But first I will discuss the cultural significance of the tarima, an artefact that materialises and articulates collective action at fandangos.

\section{Tarima}

The seamless integration of dance, instrument playing and verses that takes place at fandango acquires its full collective meaning by being enacted in 


\section{The heartbeat of fandango}

relation to a stomp-box called the tarima. The tarima is a platform made of several wooden planks that together form a large box on which practitioners dance. It rests on its sides, which have holes that enhance the resonance produced when dancers stomp on it with hard-soled shoes. While it may look like a rustic stage, this platform is not used as a surface on which entertainers become visible, and thereby differentiated from an audience. The tarima is a percussive instrument that rhythmically structures the unfolding of performance. Acoustically, the tarima is built with specific material characteristics in mind: its top must be firm and resistant as it will be hit simultaneously with the hard-soled shoes of at least six dancers. At the same time, it must be flexible enough to cushion the strikes and to resonate like a deep stomp-box. Tarimas made of oak tend to be hard and sturdy; mahogany offers a good balance between resonance and solidity (although it can be expensive); and pine and mango tree are also good materials, but are only available in certain places. The physical qualities of the tarima are relevant for the way in which fandango unfolds, and for the embodied/mental schemata of dancers and musicians.

The relevance of the tarima can hardly be exaggerated, as it constitutes the heartbeat of fandango. It is by far the biggest instrument in the performance, and its commanding resonance marks the beat. Llevar el golpe (to carry the beat) is the duty of dancers, which refers to the ability to sustain a steady pulse and to articulate distinct rhythms for each theme. Practitioners

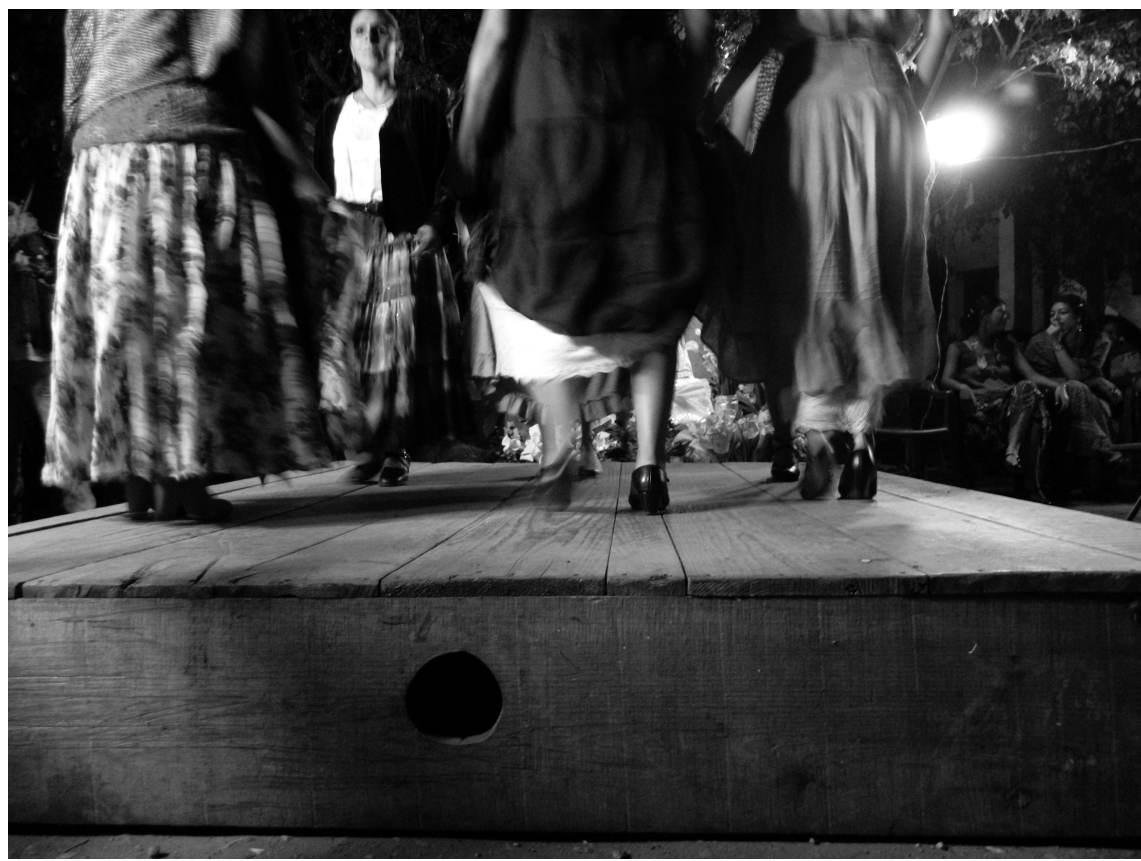

Figure 1.1 Tarima and dancers 
appreciate it when dancers highlight the differences of every piece of the repertoire and bring rhythmic variety by dancing each $s^{2} n^{2}$ with a distinct cadencia. $^{3}$ For this reason, skilled dancers pay attention to the volume and timbre of the tarima on which they are dancing in order to regulate their steps as the performance unfolds. Dancers do not only display their skills through the elegance of their movements, but primarily through their competency as rhythm makers, as percussionists. For instance, when the performance is building momentum there are peaks in which dancers aprietan (tighten it up) by stomping more effusively, inducing the musicians gathered around them to play with even more intensity. It is highly emotive when everyone around the tarima moves at the same pulse and is completely focused on the same rhythmic 'feel'. Practitioners commonly describe this effect as playing amarrado (tight, tied up), which is a way of saying that participants and instruments hang together and resonate around the same tarima. Here Marco, ${ }^{4}$ a practitioner who has been making son jarocho in Sotavento and different cities in Mexico for decades, explains the significance of tarima in the context of fandango:

This celebration [fandango] is something close to a ritual; it is a space. Look, it is an incredible thing when you go to a ranchería [a small rural settlement] and people take the tarima, either from the place in which the celebration happens, or from a different place. Some carry the tarima and say 'Hey, Don Fulanito, ${ }^{5}$ where are we placing the tarima?' And Don Fulanito says 'Eh ... let's place it there.' And that place, that little area, becomes a sacred place, because wherever you place that thing ... I'm going to say it in an 'ugly' way, because if you look at the tarima without this understanding, it is just a mouldy piece of wood, isn't it? But wherever we place that piece of wood, right there, that very place becomes a magical thing, because around that simple piece of wood everything happens. Romantic relationships come! From there comes the possibility for me to sing the verse I learnt! The possibility that I meet other people! That I meet with that dear friend I haven't seen in a long time! The possibility of meeting that great jaranero and playing beside him! ${ }^{6}$ That thing, all the respect, all the mysticism that happens around that piece of wood, happens only because everyone keeps a ritualistic attitude. Do you see?

Regardless of austerity or opulence, it would be unthinkable to have a fandango without a tarima; its presence is a basic condition for the celebration to take place. This collective achievement that Marco refers to as 'ritualistic attitude', this 'practical belief' (Bourdieu 1990: 68) in the activities that take place, is enacted around this artefact. Its significance in the context of fandango reveals how materials enable and constrain the unfolding of events and, more generally, how their materiality is a constituent of the social (Schatzki 2010a: 123). An example of the relevance of the tarima comes from a fandango that I attended in San Diego, California. We were not celebrating anything in particular, and simply decided to meet up for the mere interest of playing and 


\section{The heartbeat of fandango}

dancing together. Helena, a friendly jaranera who has been very active at the son jarocho scene of California, picked me up in East Los Angeles and we headed south. A few hours later we arrived in Balboa Park in San Diego and started walking around, looking for the fandango. The Facebook invitation indicated that we were meeting 'by the fountain', but we soon realised that it was going to be a bit complicated to find the fandango as there were several fountains in the park.

We spent some time watching people walking their dogs, and kids eating ice cream, until we saw a girl with a jarana hanging from her right shoulder. She was also looking for the fandango and had already spent half an hour looking for familiar faces. We saw a small group of people gathered by one of the fountains, and by sunset we had formed a group of around twenty people switching between English and Spanish, tuning instruments and eating snacks. One hour later, we all had our instruments in tune, avoided switching languages (because of linguistic fatigue) and had already eaten enough snacks. I was holding my instrument with impatience, wondering when we were going to get started. Surprisingly, nobody dared to start playing and there was no need to ask why: the person bringing the tarima had not arrived yet; thus, playing without it would be like attempting to start a football match without a ball. Two young men finally arrived carrying the tarima, apologising for being late and recounting the mechanical problems they had had with their truck. There is no fandango without the tarima because its use is a condition for the event to occur.

The spatial dynamics around the tarima are meaningful because this artefact is the epicentre of the action. It is commonly understood that the hosts of the fandango, locals and the most knowledgeable musicians stand closer to the tarima because they can be heard clearly by the dancers, who in turn develop the groove with their stomping. Traditionally, it is the requintero ${ }^{7}$ (a person who plays the requinto, also called guitarra de son $)^{8}$ who stands close to the edge of the tarima and leads the fandango by deciding what sones from the traditional repertoire are going to be played, as well as their sequence, tempo, key, mode and cadencia. Being physically positioned close to the tarima is crucial to influencing dancers' stomping and, most importantly, to deciding when to begin and finish a son. The spatio-temporal order maintained around the tarima is not explicit because it is presumed by practitioners; and, in the case of new apprentices like me, it suffices to imitate what the most experienced do. The mechanisms of these tacit understandings can be better appreciated by analysing the way in which fandango unfolds.

\section{A festivity unfolding}

I attended a fandango in Chacalapa, a rural town in southern Veracruz. The celebrations at this particular location are famous among jaraneros to the extent that conversations about them acquire a mythical character. Prior to that event, I spent a few weeks hanging out with jaraneros of this region, 
particularly around Cosoleacaque, Chinameca and Chacalapa. These towns have been historically connected by trade, roads and people who go back and forth to shop, visit relatives or catch buses to larger cities. As other son jarocho practitioners, I travelled to workshops, fandangos and other gatherings by bus, taxi and privately owned vans that function as public transport. On these trips I visited groups of young jaraneros who organise son jarocho workshops and occasionally gather in the afternoons to play casually when the sun sets and the heat recedes. My expectation regarding the fandango in Chacalapa was growing as they reiterated how these events were the 'real thing', just like 'those made many years ago, when the old jaraneros were younger'.

One afternoon I was travelling by taxi from Chinameca to Chacalapa with José, a young jaranero with whom I was going to the fandango. José had kindly offered to host me that night and we were making a quick stop at his house before heading to the celebration. Inside the house was a large room divided into three sections; the kitchen was on my right-hand side, where José's mother and her neighbour were having a lively conversation while washing dishes. After greetings and introductions I went to the opposite side of the room to drop my backpack. The left end of the room was a bit darker, but I noticed a hammock bouncing slowly. A young man said 'Hi' and then started playing chords with a small jarana. I introduced myself and sat down on a couch nearby.

'Nice jarana', I said.

'My father made it, I've been struggling to get it in tune the whole afternoon', he replied and then tried a few chords as if testing the tuning, slowly strumming the strings absentmindedly without any regular rhythm.

He continuously stared at a fixed point on the ceiling and never turned his head to the jarana or to me; I then realised that he was blind. He twisted one of the wooden tuning keys because it did not sound quite right yet. He tested it again, but this time he strummed chords in a steady manner, as if playing a son. That sounds like 'El Pájaro Cú', I thought. ${ }^{9}$ How did I recognise that son? Habits grow quickly in the field, and I was attaining the capacity to recognise musical pieces not by their melody, but by their rhythm, phrasing and chord progression. The smell of beans and fried pork filled the entire room.

'My mum says dinner is ready', José said, and when I turned to the kitchen I saw his mother walking towards the door.

'Have a good time, guys', she said in a rush. Then she turned to me: 'Please make yourself at home.'

José and I sat and ate silently; it was already dark and we were listening to the crickets and the chords of 'El Pájaro Cú' that José's brother was distractedly playing. Silence can be uncomfortable when one is a visitor in an 
unknown environment, but at that moment starting a conversation felt unnecessary, as there were plenty of surrounding sounds already. Perhaps we were getting ready to be imbued with the solemn attitude of fandango.

'I'll do the dishes', I said as we were finishing eating.

'No, buddy, you are having a shower. Are you going to the fandango looking like a tourist?'

I laughed and then realised that he was right: sandals, shorts, t-shirt, backpack and camera would certainly not help me blend in; but then I also noticed that José spoke those words with a subtle, commanding tone, as if letting me know that I should take the occasion a little more seriously. By the time we were leaving his house, José was wearing shiny, sturdy shoes and a nice white shirt. I did my best with tennis shoes and a wrinkled shirt from my backpack. The occasion required setting up certain conditions, such as dressing a little better than usual. This gesture is not a rule, but a way of establishing the conditions for an event that is taken seriously. The ritualistic character of fandango emerges before the actual celebration starts.

After a brief walk on Chacalapa's main road we turned onto a dirt road. From a distance I could see parked cars on both sides and dozens of chairs carefully arranged in rows, facing two big light reflectors that pointed towards a large tarima right in the centre of the road. On one side there was a Catholic shrine decorated with colourful fabric and flowers. Some people were already there, most of them standing, talking, laughing, shaking hands and effusively greeting old friends. By the number of chairs I could tell that they were anticipating many more people as the night progressed. 'Now you'll see what's a good one, the best fandangos are in Chacalapa', said José with a wide smile. Most of the attendees seemed to know each other and held animated conversations. Some men were gathered around the tarima, right opposite where the chairs were arranged. As they started to tune their jaranas, José turned to me and said, 'Don't stand there just watching, let's tune.'

It is expected that people who come from other regions to join the fandango adjust their playing to the local style; tuning one's instrument is a good example of this practice. I took my jarana and asked for the note used as reference to tune. When tuning a jarana, one normally starts with the upper string and continues to tune the rest, taking that string as a reference point. I knew that the note taken as a reference should be G, but could not be more wrong that night: I later understood that tuning son jarocho instruments using equal temperament with a reference of A as 440 Hertz is rare. ${ }^{10}$ In the twentieth century, the frequency of 440 Hertz became the tuning standard for the musical note $\mathrm{A}$ above the middle $\mathrm{C}$; that is the reference that contemporary musicians use to tune most instruments. However, the tuning practices of son jarocho usually differ from that canon because there is a continuity of archaic tunings based on those of renaissance and baroque music (García de León 
2002: 125). As will be analysed in Chapter 3, tuning practices are not simply a stylistic choice, but an expression of belonging to a tradition.

After tuning I noticed that the strings were more tense than usual; that night the note used as reference was almost one tone higher than a tempered G. Using higher tones to tune these instruments increases the tension of the strings, projecting a slightly brighter and louder sound. However, the more tense the strings, the harder it is to play them. People in Chacalapa are proud of their musicians, dancers and challenging fandangos. That night the local and experienced musicians who set the tuning did not make it easy for others, and it was expected that everyone submit to those dispositions by approaching the tarima with one's instrument and asking for the tone of reference. Tuning around the tarima, like many other routines, is an unspoken activity that rests on implicit understanding. To become a practitioner involves not only following such conventions, but also accepting them as inherent elements of the practice.

Fandangos have routines and rules that allow practitioners to anticipate a series of interconnected events. Yet, these events stand in stark contrast to the predictive evolution of staged musical performances, as there is no previous rehearsal. In other words, there is a series of conventions that allows practitioners to perform jointly, but nobody knows the exact way in which the events will unfold. One of the most immediate problems encountered at fandangos is the issue of starting together. How can practitioners engage in collective action if there is no previous rehearsal in which a starting point is agreed? The drummer of a rock band can count to four by hitting the drumsticks to make sure that everyone starts at the same time. Members of a classical string quartet are attentive to the subtle sign (a slight nodding and breathing gesture) that precedes the beginning of a piece. Yet, these are instances of well-rehearsed groups in which clear starting points are marked. In the case of fandangos, the beginning of a son is given by a call for participation that in the practitioner's jargon is named declaración (to declare or state). A melody played by a single instrument (guitarra de son) announces the piece to be played and establishes the tempo, key and rhythmic 'feel'. That night in Chacalapa, José, a dozen other musicians and I were standing around the tarima, chatting, making jokes, laughing, checking the tuning of our instruments and waiting for something to happen. Away from the tarima people talked loudly, standing scattered in small groups along the dirt road. Kids were running around playing a game of chasing each other, a baby was crying in the arms of a mother, dogs were barking in the distance and there was an incessant buzz of crickets. In the middle of all that noise emerged a single melody, executed as loudly as possible (as much as an acoustic, nylon-stringed instrument allows) and, in a matter of seconds, we were strumming with our jaranas a son called 'El Siquisirí'. Everyone knew when to start. Those who seemed distracted were effortlessly responding to a melodic call in the same way that one joins a conversation after hearing the call of a friend. The man who played the declaración was leading the fandango by standing in front of the tarima; another person was playing deep bass melodies with a leona; and the rest of 


\section{The heartbeat of fandango}

us provided a harmonic base by strumming chords in our jaranas. I could barely see the tarima from that point as I was standing behind the musicians following the same rhythmic pulse and reproducing sequences of chords (G7, C, F) almost intuitively. We spent some time (a minute or two, perhaps) repeating the same chord progression, getting used to the cadencia, testing if one's playing was too loud or too soft, assimilating the ambience created by more than a dozen acoustic instruments being played simultaneously in the middle of a dirt road. The repetition of the same chord progression and strumming patterns had already established a sonic surface on which other events were about to happen. I turned to see what José was doing; he appeared to be busily trying to recognise who had just arrived and was not even looking at his instrument. His manipulation of the jarana was so effortless it was almost as if the instrument had disappeared from his hands. Still, his strumming was loud and followed the same tempo as the rest. Someone by the tarima sang (almost yelled) the first verse that, in the form of rhyme, asks for permission to begin: ${ }^{11}$

$\begin{array}{ll}\text { Divino cielo te ruego } & \text { Divine heaven I ask you } \\ \text { permiso para cantar } & \text { permission to sing } \\ \text { permiso para cantar } & \text { permission to sing } \\ \text { divino cielo te ruego } & \text { divine heaven I ask you. }\end{array}$

Another person sang exactly the same words, but with a slightly different melody. It was a form of call and response, almost like a conversation in which the first singer asserts and the second replies. After the response, the first singer continued with the second part of the verse:
me contesta luego, luego
and it answers at once
empieza por saludar, start by greeting, empieza por saludar, start by greeting, agua, tierra, viento y fuego, water, earth, wind and fire.

This musical piece has a fixed verse structure in which the first person sings four octosyllabic lines and the respondent reproduces exactly the same words with a melodic variation. After completing four octosyllables there is a shorter call-response that builds up and finishes with three concluding octosyllables from the first singer:

1st singer:

ay que sí, que no, que no cuánto gusto me da verte

2nd singer:

ay que sí, que no, que no oh yes, oh no

I'm so glad to see you 
1st:

déjame darte un abrazo

2nd:

cuánto gusto me da verte

1st:

le doy gracias a mi suerte

2nd:

ay que sí, que sí, que no

1st:

por que con el tiempo acaso

por que con el tiempo acaso

más y más pueda quererte let me give you a hug

I'm so glad to see you

I thank my luck

oh yes, oh no

because perhaps on time

because perhaps on time

I could love you more and more.

This sequence constitutes a full verse, which is usually followed by an interlude in which dancers show their rhythmic skills by stomping on the tarima. After that interlude, another person starts a new verse, repeating the same pattern but rotating the participation among singers. Later that night, as the fandango unfolded, José encouraged me to sing a verse by using short utterances such as vas! (go on) or échale! (take this turn). I did want to sing a verse and, in fact, I had learnt a few of them in workshops. But I just could not do it. The mere idea of taking a singing turn made me nervous to the point of forgetting the rhymes, and I did not want to start a verse and leave it unfinished. Taking part in collective performances involves forms of exposure that trigger personal insecurities which, in this case, were aroused by my inability to know what was going to happen next. As a beginner, I was confident to strum my jarana at the back of the group because I could follow the chord progression and the strumming pattern. But I was unsure about the right moment to intervene with a verse, as I could not anticipate who was going to sing next. Participation at fandangos is inherently temporal practitioners are not looking at, or listening to, specific points in time, but have a comprehensive understanding of what has just happened and can pre-empt what is about to happen.

Organising verses into patterns of call-response makes participation intuitive, but it took me several fandangos to gain a tacit understanding of how the sequence of singers is articulated. As there are no queues or any other explicit principle that structures sequential participation, the rotation of singers relies 
on their capacity to read each other's gestures, such as slightly leaning forward, breathing deeply before starting a verse or moving a little before responding to a verse. Interpreting and responding to quick, spoken utterances and bodily gestures is a skill that requires an acute sense of timing. Nobody knows how the sequence of verses is going to unfold; yet, seasoned practitioners know when to intervene, when to stop and how to motivate other practitioners to participate. Now that I can reflect on this field experience with the passage of time, I realise how those interventions are timed assessments of complex interactions. José encouraged me to sing when he estimated that it was the right moment through evaluation of who sang before and who could potentially respond to my verse. José (and, more generally speaking, any person engaged in performative practices) understands and acts upon the process of performing as 'the coming-into-sight and passing-out-of-sight of variously contoured and textured surfaces' (Ingold 2000: 238-239). José negotiates his bodily movements in relation to an environment that is unfolding, just like a person who negotiates their movements while travelling on foot, keeping a steady pace and avoiding obstacles. This capacity to seize the situation (to assess what has just happened and guess what is about to happen) and act accordingly is what Bourdieu (1998: 25) calls 'practical sense' or the art of anticipating.

The practical sense attained by son jarocho practitioners allows them to anticipate what comes next and, consequently, to move smoothly across a series of entangled actions. The more skilled a practitioner, the less effort is invested in these movements. The continuous alternation of singers is similar to the way in which people transit at a busy railway station. The reading of bodily gestures and the subsequent actions - such as deciding who is passing first or if one should quickly move aside to clear the way - take a fraction of a second. In fandangos, as in railway stations, it can be irritating when someone blocks the way; thus, only two people at a time are expected to engage in the same verse, and then they let others sing as well. If two people accidentally start a verse at the same time there is an implicit courtesy, which is based on the common understanding that they should allow other practitioners to participate too. Occasional cases of rivalry between two practitioners are likely to take the form of displaying skill at dancing, singing or playing an instrument, instead of intentionally blocking the participation of others. Continuing with the station metaphor, the implicit courtesy is like waiting to board the train on a crowded platform: everyone will eventually step in and out, but one should be aware of the presence of other people and read their movements to avoid clashing. But, in contrast to our station metaphor, fandangos rarely have a peak-hour and there is no need to rush. There is space for everyone to sing if they want to, to pluck their stringed instruments, to step on the tarima, or simply to rest on a chair watching others doing it.

After some verses have finished, it is time for the dancers to take over. That was the case in Chacalapa, where a few verses had already been sung 


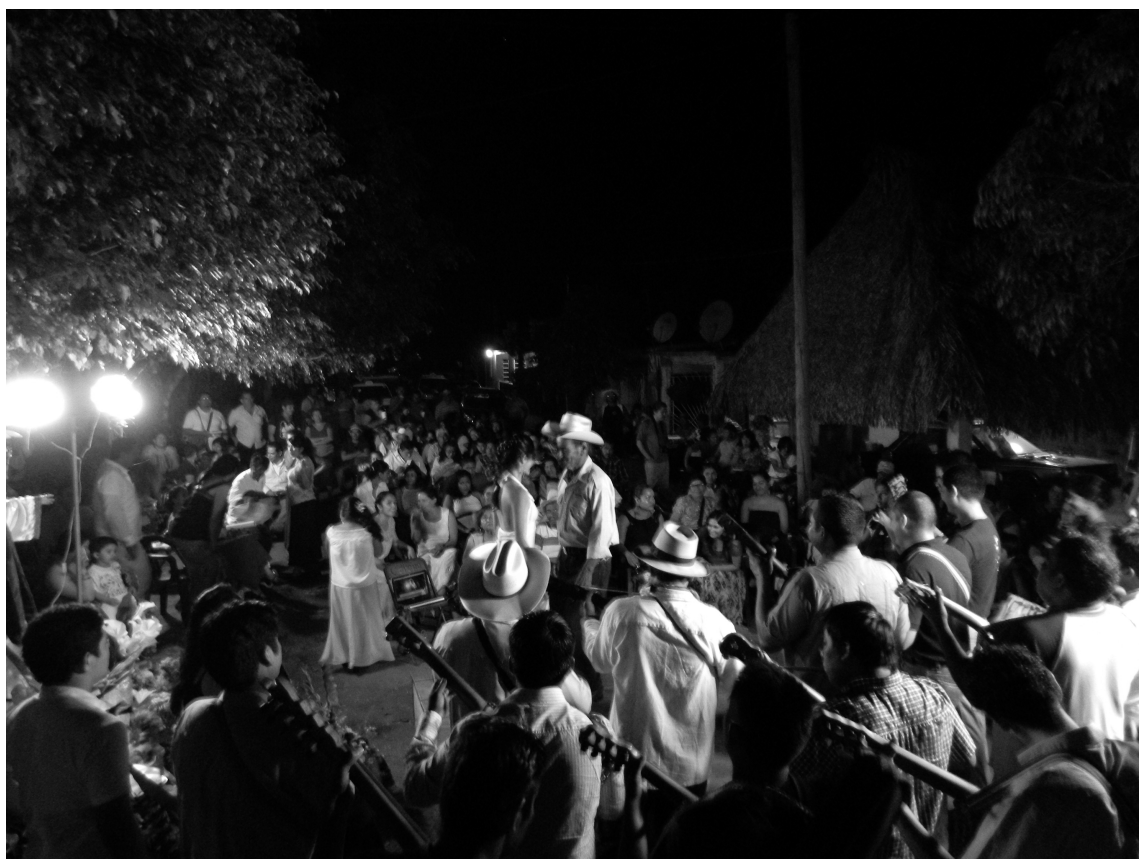

Figure 1.2 Fandango unfolding

but there were still no dancers on the tarima. Singers used the first verses to ask for permission to start, greet the people present on that occasion, apologise for their self-attributed hoarseness and invite women to dance. The latter finally made their way to the tarima and stepped onto it with timely precision, right at the end of a verse, and so marking the rhythms of a pattern known as café con pan. ${ }^{12}$ The dancers' percussive intervention is known as zapateado, which refers to the rhythmic stomping on the tarima that takes place while no verses are sung. ${ }^{13}$ Another verse was started and the dancers ceased stomping on the tarima, conducting muted steps instead, and allowing singers to be heard. The objective of this alternation is to establish a constant interplay between verses and percussive dance. Those playing instruments around the tarima also imitate this performative oscillation by playing quieter when a verse is sung and louder when dancers are performing zapateado. Every time a verse is finished, a new group of dancers can step onto the tarima and replace the previous ones, resulting in a constant circulation of dancers, singers, players, chords, melodies and rhythmic patterns. This continuous motion must stop at a certain point, but the fact of it being a non-rehearsed performance brings up the issue of how practitioners may finish together. Starting and finishing the performance together is crucial for the establishment of the temporal and spatial orders at fandango, which is a type of alignment of actions that turns this performance into an engaging activity. 


\section{The heartbeat of fandango}

Sones, the pieces of the traditional son jarocho repertoire, normally last long enough (compared to what is commonly assumed to be standard song length) to allow sufficient time for dancers and singers to display their skills. But, how to know when to stop playing or dancing? The guitarrero who leads the fandango assesses if the participants have satisfied their eagerness to dance before starting a set of versos de salida (closing verses) that are either sung either by him or by others around the tarima. ${ }^{14}$ These verses are the first sign that the son is coming to an end, followed by rhythmic indications such as the accentuation of the first beat and a gradual decrease of speed. Fandango, to repeat, is not a concert but a gathering full of noise and distractions; therefore, the most effective ways to indicate the end of a son are nodding, moderately raising one's instrument and yelling una!

When a son finishes one leaves the tarima and goes to chat with others, or to get something to eat or drink. After a while, the guitarrero goes back to the edge of the tarima, plays a melody calling for a new son and the performance starts again. Every new son results in a different combination of participants and instruments because some people choose to dance instead of play, or take a different instrument, or simply take a rest. Local and experienced musicians in front of the tarima are in control, but the commanding position also rotates at some point. As I was re-tuning my jarana that night in Chacalapa, Roberto, a jaranero from Cosoleacaque, told me how he was waiting for the men at the front to leave the tarima so we could take the lead: 'Relax, this is just fun, my friend. We'll take over soon! This is just show time. ${ }^{, 15}$ As Roberto affirms, the successive leading of the fandango is also a timed activity. The temporal character of this rotation is an example of the multiple rhythms through which the unfolding of fandango is sustained.

Every fandango inevitably starts with 'El Siquisirí'. There is no apparent explanation as to why this is so, although some practitioners were keen to recall assorted reasons when I asked them about it: this son is good as a warm-up; the flexibility of its theme enables the construction of verses for different occasions; it is one of the easiest sones and encourages participation; or the word siquisirí is derived from its refrain - que sí, que sí (yes, yes). Starting fandangos with this son has been replicated from generation to generation. This canon is not questioned; it constitutes a tradition that has been reproduced as the practice moves. 'El Siquisirí' belongs to a category of sones called de a montón (danced in groups), which are danced exclusively by groups of women. Some other sones are de cuadrilla (danced by four women and one man) or de pareja (danced in couples). The latter are the most challenging ones and are reserved for the 'peak' of the night as dancers are expected to gauge their skills in a duel between a woman and a man. As the night unfolds, the exciting tunes are replaced by more placid ones called sones de madrugada (dawn themes), which are sung in a tranquil way. That arrangement allows people to stretch the event some more hours, until dawn if possible. As Marco describes below, fandangos that last until dawn become memorable events: 


\section{References}

Adey, P. (2006) 'If mobility is everything then it is nothing: Towards a relational politics of (im)mobilities', Mobilities, 1(1): 75-94.

Adey, P. , Bissell, D. , Hannam, K. , Merriman, P. and Sheller, M. (eds.) (2014) The Routledge Handbook of Mobilities. London: Routledge.

Adorno, T. (1976) Introduction to the Sociology of Music. New York: Continuum.

Adorno, T. (2002) Essays on Music. California: University of California Press.

Aguirre Tinoco, H. (1983) Sones de la Tierra y Cantares Jarochos. Mexico City: Premiá Editora. Alcántara López, A. (2010) 'Los fandangos de tarima del sur de Veracruz: Fiesta del son jarocho', in J. Chacha Antele , Veracruz. Cuna del Son Jarocho. Veracruz: Tenaris-Tamsa. Anderson, B. and Harrison, P. (2010) Taking-Place: Non-Representational Theories and Geography. Farnham: Ashgate.

Ang, I. (2001) On Not Speaking Chinese: Living between Asia and the West. London: Routledge.

Arboleyda Castro, P. (2004) 'La jarana y el requinto jarochos', Conferencia en el VIII Encuentro Nacional de Guitarra. Escuela de Laudería del INBA, Santiago de Querétaro, 22 April 2004. Archer, M. S. (1996) Culture and Agency: The Place of Culture in Social Theory. Cambridge: Cambridge University Press.

Ávila Domínguez, F. , Pérez Montfort, R. and Rinaudo, C. (eds.) (2011) Circulaciones Culturales: Lo Afrocaribeño entre Cartagena, Veracruz y la Habana. Mexico City: (CIESAS). Baer, H. A. (2009) 'Waiting for global warming: Climate politics in Australia - perspectives from above and below', in G. Hage (ed.) Waiting. Melbourne: Melbourne University Press.

Bailey, D. (1993) Improvisation: Its Nature and Practice in Music. Boston, MA: Da Capo. Balcomb, H. E. A. (2012) Jaraneros and Jarochas: The Cultivating of Fandangos and Son Jarocho in Los Angeles: Meanings of Immigrant and Diasporic Performance. Master thesis, University of California, Riverside.

Banks, M. (2012) 'MacIntyre, Bourdieu and the practice of jazz', Popular Music, 31(1): 69-86. Baqueiro Foster, G. (1942) 'El huapango', Revista Musical Mexicana, 1(8): 174-183.

Barahona Lodoño, A. (1997) 'Ángel de Sotavento: El arpa jarocha', Sotavento: Revista de Historia, Sociedad y Cultura, 1(1): 147-161.

Barahona Lodoño, A. (2013) Las Músicas Jarochas: ¿De Dónde Son? Un Acercamiento Etnomusicológico a la Historia del Son Jarocho. Xalapa: Testimonios Jarochos. Available from: tlanestli.blogspot.com.au/2013/05/las-musicas-jarochas.html [ 12 July 2013 ].

Barnes, B. (2005) 'Practice as collective action', in T. R. Schatzki , K. Knorr-Cetina and E. von Savigny (eds.) The Practice Turn in Contemporary Theory. London: Routledge. E-book available from: ebookstore.tandf.co.uk [ 18 March 2013 ].

Bartra, B. (2017) 'Son jarocho in New York: Jarana and fandango as symbols of a new Mexican identity', in K. Meira Goldberg and Antoni Pizà, The Global Reach of the Fandango in Music, Song and Dance: Spaniards, Indians, Africans and Gypsies. Newcastle: Cambridge Scholars. Baudot, G. and Méndez, M. A. (1987) 'El chuchumbé, un son jacarandoso del México virreinal', Caravelle, 48: 163-171.

Baumann, G. (1997) 'Dominant and demotic discourses of culture: Their relevance to multiethnic alliances', in P. Werbner and T. Modood (eds.) Debating Cultural Hybridity: Multi-Cultural Identities and the Politics of Anti-Racism. London: Zed Books.

Bennett, A. (1999) 'Hip hop am Main: The localization of rap music and hip hop culture', Media, Culture \& Society, 21: 77-91.

Benveniste, T. (1971) Problems in General Linguistics. Miami: University of Miami Press.

Bermudo, J. (2009 [1555]) Declaración de Instrumentos Musicales. Valladolid: Maxtor.

Born, G. (2013) Music, Sound and Space: Transformations of Public and Private Experience. New York: Cambridge University Press.

Bourdieu, P. (1986) 'The forms of capital', in J. G. Richardson (ed.) Handbook for Theory and Research for the Sociology of Education. New York: Greenwood.

Bourdieu, P. (1990) The Logic of Practice. Stanford: Stanford University Press.

Bourdieu, P. (1995) The Rules of Art: Genesis and Structure of the Literary Field. Stanford:

Stanford University Press.

Bourdieu, P. (1998) Practical Reason: On the Theory of Action. Stanford: Stanford University Press. 
Bourdieu, P. (2000) Pascalian Meditations. Stanford: Stanford University Press.

Brubaker, R. (2004) Ethnicity Without Groups. Cambridge, MA: Harvard University Press.

Burawoy, M. (2009) The Extended Case Method: Four Countries, Four Decades, Four Great

Transformations, and One Theoretical Tradition. Berkeley: University of California Press.

Busby, T. (1827 [digitised in 2010]) A Complete Dictionary of Music. New York: Snider.

Available from: books.google.com.au [ 20 September 2014 ].

Callon, M. (1986) 'Some elements of a sociology of translation: Domestication of the scallops and the fishermen of St. Brieuc Bay', in J. Law (ed.) Power, Action and Belief: A New Sociology of Knowledge. London: Routledge.

Camastra, C. (2006) 'Lotería de sones jarochos: La emblemática en la cultura popular', Revista de Literaturas Populares, 6(1): 128-152.

Campbell, M. and Campbell, P. (2010) 'Viols and other historic bowed string instruments', in T.

D. Rossing (ed.) The Science of String Instruments. New York: Springer.

Canzler, W. , Kaufmann, V. and Kesselring, S. (eds.) (2008) Tracing Mobilities: Towards a

Cosmopolitan Perspective. Aldershot: Ashgate.

Cardona, I. (2006) 'Los actores culturales entre la tentación comunitaria y el mercado global: El resurgimiento del Son Jarocho', Política y Cultura, 26: 213-232.

Cardona, I. (2011) 'Fandangos de cruce: La reapropiación del son jarocho como patrimonio cultural', Revista de Literaturas Populares, 11(1): 130-146.

Castles, S. and Delgado Wise, R. (eds.) (2008) Migration and Development: Perspectives from the South. Switzerland: International Organization for Migration.

Clifford, J. (1997) Routes: Travel and Translation in the Late Twentieth Century. Cambridge, MA: Harvard University Press.

Clifford, J. (2003) On the Edges of Anthropology (Interviews). Chicago: Prickly Paradigm Press. Coleman, S. and von Hellermann, P. (eds.) (2011) Multi-Sited Ethnography: Problems and Possibilities in Translocation of Research Methods. New York: Routledge.

Connell, J. and Gibson, C. (2003) Sound Tracks: Popular Music, Identity and Place. New York: Routledge.

Covarrubias Orozco, S. (1611 [digitised in 2010]) Tesoro de la Lengua Castellana o Española. Madrid: Luís Sánchez. Available from: books.google.com.au [ 3 January 2014 ].

Cresswell, T. (2006) On the Move: Mobility in the Modern Western World. New York: Routledge. Cresswell, T. (2010) 'Towards a politics of mobility', Environment and Planning D: Society and Space, 20: 17-31.

Cresswell, T. (2014) 'Friction', in P. Adey, D. Bissell , K. Hannam , P. Merriman and M. Sheller (eds.) The Routledge Handbook of Mobilities. London: Routledge.

Cresswell, T. and Merriman, P. (eds.) (2011) Geographies of Mobilities: Practices, Spaces,

Subjects. Farnham: Ashgate.

Cwerner, S. B. (2000) 'The chronopolitan ideal: Time, belonging and globalization', Time \& Society, 9(2/3): 331-345.

Cwerner, S. B. (2001) 'The times of migration', Journal of Ethnic and Migration Studies, 27(1): 7-36.

De Certeau, M. (1984) The Practice of Everyday Life. Berkeley: University of California Press. Delgado Calderón, A. (1995) 'Los negros del sur', Son del Sur, 1: 27-32.

Delgado Calderón, A. (1996) 'El quehacer institucional en el son jarocho', Son del Sur, 2: 40-45.

Delgado Calderón, A. (1997) 'El diablo y el fandango', Son del Sur, 4: 28-30.

Delgado Calderón, A. (2004) Historia, Cultura e Identidad en el Sotavento. Mexico City:

Consejo Nacional para la Cultura y las Artes (Conaculta).

Delgado Wise, R. and Favela, D. M. (2004) Nuevas Tendencias y Desafíos de la Migración Internacional México-Estados Unidos. Mexico City: UNAM.

DeNora, T. (2003) 'Music sociology: Getting the music into the action', British Journal of Music Education, 20(2): 165-177.

DeNora, T. (2004) 'Musical practice and social structure: A toolkit', in E. Clarke and N. Cook (eds.) Empirical Musicology: Aims, Methods, Prospects. New York: Oxford University Press. DeNora, T. (2014) Making Sense of Reality: Culture and Perception in Everyday Life. London: Sage. 
Dewey, J. (2005) Art as Experience. New York: Perigee.

Edensor, T. (2010) Geographies of Rhythm: Nature, Place, Mobilities and Bodies. Farnham:

Ashgate.

Edensor, T. (2011) 'Commuter: Mobility, rhythm and commuting', in T. Cresswell and P.

Merriman (eds.) Geographies of Mobilities: Practices, Spaces, Subjects. Farnham: Ashgate.

Falzon, M. (2009) Multi-Sited Ethnography: Theory, Praxis and Locality in Contemporary

Research. Farnham: Ashgate.

Fen, E. (2012) 'Rhythmanalysis perspective for mobile places studies', Journal of New Frontiers in Spatial Concepts, 4: 48-52.

Figueroa Hernández, R. (2007) Son Jarocho: Guía Histórico-Musical. Mexico City: ConacultaFONCA.

Figueroa Hernández, R. (2014) El Son Jarocho en los Estados Unidos de América:

Globalizaciones, Migraciones e Identidades. PhD thesis, Universidad Veracruzana, Mexico.

Fitzgerald, D. (2006) 'Towards a theoretical ethnography of migration', Qualitative Sociology, 29(1): 1-24.

Fletcher, N. H. and Rossing, T. D. (1998) The Physics of Musical Instruments. New York:

Springer.

Friedman, J. (2002) 'From roots to routes: Tropes for trippers', Anthropological Theory, 2(1): 21-36.

Frith, S. (1989) World Music, Politics, and Social Change. Manchester: Manchester University Press.

García de León, A. (1994) 'Contrapunto barroco en el Veracruz colonial', in B. Echeverría (ed.) Modernidad, Mestizaje Cultural, Ethos Barroco. Mexico City: UNAM/El Equilibrista.

García de León, A. (1996) 'Son de una tierra fertilísima', Son del Sur, 2: 29-32.

García de León, A. (2002) El Mar de los Deseos: El Caribe Hispano Musical. Historia y

Contrapunto. Mexico City: Siglo XXI.

García de León, A. (2009) Fandango: El Ritual del Mundo Jarocho a través de los Siglos.

Mexico City: Conaculta.

García de León, A. (2011) Tierra Adentro, Mar en Fuera: El Puerto de Veracruz y su Litoral a

Sotavento, 1519-1821. Mexico City: Fondo de Cultura Económica.

García, F. and Gutiérrez, R. (2002) La Guitarra de Son, Tomo I. Veracruz: Instituto Veracruzano de Cultura.

Gault, R. (1995) 'In and out of time', Environmental Values, 4: 149-166.

Goffman, E. (1989) 'On fieldwork', Journal of Contemporary Ethnography, 18: 123-132.

Grzymala-Busse, A. (2011) 'Time will tell? Temporality and the analysis of causal mechanisms and processes', Comparative Political Studies, 44(9): 1267-1297.

Gutiérrez, G. and Pascoe, J. (2003) La Versada de Arcadio Hidalgo. Veracruz: Universidad Veracruzana.

Hage, G. (2005) 'A not so multi-sited ethnography of a not so imagined community',

Anthropological Theory, 5: 463-475.

Hage, G. (2009) 'Waiting out the crisis: On stuckedness and governmentality', in G. Hage (ed.) Waiting. Melbourne: Melbourne University Press.

Hall, S. (1996) 'Introduction: Who needs “identity"?', in S. Hall and P. du Gay (eds.) Questions of Cultural Identity. London: Sage.

Hall, S. (2012) City, Street and Citizen: The Measure of the Ordinary. New York: Routledge. Hall, S. and du Gay, P. (eds.) (1996) Questions of Cultural Identity. London: Sage.

Hannam, K. , Sheller, M. and Urry, J. (2006) 'Editorial: Mobilities, immobilities and moorings', Mobilities, 1(1): 1-22.

Hannerz, U. (2003) 'Being there ... and there ... and there!', Ethnography, 4(2): 201-216.

Hasty, C. (1997) Meter as Rhythm. New York: Oxford University Press.

Hennion, A. (2001) 'Music lovers: Taste as performance', Theory, Culture \& Society, 18(5):

$1-22$.

Hennion, A. (2007) 'Those things that hold us together: Taste and sociology', Cultural

Sociology, 1(1): 97-114.

Hernández Palacio, E. and Obrador Cuesta, M. (2011) 'El son jarocho en California: Coplas y versadas migratorias', in N. Cuevas Velasco and R. Velasco González, El Norte y el Sur de México en la Diversidad de su Literatura, Mexico City: Juan Pablos. 
Hesmondhalgh, D. (2012) The Cultural Industries. London: Sage.

Hobbs, D. and May, T. (eds.) (1993) Interpreting the Field. Oxford: Oxford University Press.

Hui, A. (2012) 'Things in motion, things in practices: How mobile practice networks facilitate the travel and use of leisure objects', Journal of Consumer Culture, 12(2): 195-215.

Hui, A. (2013a) 'Moving with practices: The discontinuous, rhythmic and material mobilities of leisure', Social \& Cultural Geography, 14(8): 888-908.

Hui, A. (2013b) 'Practices, movement and circulation: Implications for sustainability', in E. Shove and N. Spurling (eds.) Sustainable Practices: Social Theory and Climate Change. London:

Routledge.

Hui, A. (2016) 'The boundaries of interdisciplinary fields: Temporalities shaping the past and future of dialogue between migration and mobilities research', Mobilities, 11(1): 66-82.

Ingold, T. (2000) The Perception of the Environment: Essays on Livelihood, Dwelling and Skill. London: Routledge.

Ingold, T. (2011) Being Alive: Essays on Movement, Knowledge and Description. Abingdon: Routledge.

Jackson, M. (2012) Between One and One Another. Berkeley: University of California Press. Jain, J. (2006) 'Bypassing and WAPing: Reconfiguring timetables for "real-time" mobility', in J. Urry and M. Sheller (eds.), Mobile Technologies of the City. New York: Routledge.

Kaufmann, V. (2002) Re-Thinking Mobility: Contemporary Sociology. Aldershot: Ashgate.

Kiwan, N. and Meinhof, U. H. (2011) Cultural Globalization and Music: African Artists in

Transnational Networks. London: Palgrave Macmillan.

Kohl, R. (2007) Ecos de 'La Bamba': Una Historia Etnomusicológica sobre el Son Jarocho de Veraruz, 1946-1959. Mexico: Instituto Veracruzano de Cultura.

Kosman, L. A. (1969) 'Aristotle's definition of motion', Phronesis, 14(1): 40-62.

Kruse, F. E. (2007) 'Vital rhythm and temporal form in Langer and Dewey', Journal of Speculative Philosophy, 12(1): 16-26.

Kuhn, T. (1996) The Structure of Scientific Revolutions (3rd edn). Chicago: University of Chicago Press.

Larsen, J. , Urry, J. and Axhausen, K. (2006) Mobilities, Networks, Geographies. Aldershot: Ashgate.

Lashua, B. and Cohen, S. (2010) 'Liverpool musicscapes: Music performance, movement and the built urban environment', in B. Fincham , M. McGuinness and L. Murray , Mobile Methodologies. London: Palgrave Macmillan.

Latour, B. (1987) Science in Action: How to Follow Scientists and Engineers through Society. Cambridge, MA: Harvard University Press.

Law, J. (1992) 'Notes on the theory of the actor-network: Ordering, strategy, and heterogeneity', Systems Practice, 5(4): 379-393.

Law, J. and Hassard, J. (eds.) (1999) Actor Network Theory and After. Oxford: Blackwell. Law, J. and Mol, A. M. (2001) 'Situating technoscience: An inquiry into spatialities', Environment and Planning D: Society and Space, 19(1): 609-621.

Le Guin, E. (2005) Boccherini's Body: An Essay in Carnal Musicology. Berkeley: University of California Press.

Le Guin, E. (2013) The Tonadilla in Performance: Lyric Comedy in Enlightenment Spain.

Berkeley: University of California Press.

Lefebvre, H. (2004) Rhythmanalysis: Space, Time and Everyday Life. London: Continuum.

Léonard, E. and Velázquez, E. (2000) El Sotavento Veracruzano. Mexico City: CIESAS.

Levi, E. and Scheding, F. (eds.) (2010) Music and Displacement: Diasporas, Mobilities, and Dislocations in Europe and Beyond. London: Scarecrow Press.

Lorimer, M. (ed.) (1987) Saldivar Codex No. 4: Santiago de Murcia Manuscript of Guitar Music (c.1732). Santa Barbara, CA: Michael Lorimer.

Loza, S. (1982) 'Origins, form, and development of the Son Jarocho: Veracruz, Mexico', Aztlán: A Journal of Chicano Studies, 13(1-2): 257-274.

Loza, S. (1992) 'From Veracruz to Los Angeles: The reinterpretation of the "son jarocho"', Latin American Music Review/Revista de Música Latinoamericana, 13(2): 179-194.

Macías Sánchez, C. (2016) La Explosión del Son y el Fandango Jarocho: Músicas, Versos y Baile para el Ritual. PhD thesis, Universidad Nacional Autónoma de México. 
Maclntyre, A. (2007) After Virtue: A Study in Moral Theory (3rd edn). Notre Dame, IN: University of Notre Dame Press.

Madrid, A. L. (2011) Transnational Encounters: Music and Performance at the U.S.-Mexico Border. New York: Oxford University Press.

Marcus, G. (1995) 'Ethnography in/of the world system: The emergence of multi-sited ethnography', Annual Review of Anthropology, 24: 95-117.

Marcus, G. (1998) Ethnography Through Thick and Thin. Princeton, NJ: Princeton University Press.

Marcus, G. (2011) 'Multi-sited ethnography: Five or six things I know about it now', in S. Coleman and P. von Hellermann (eds.) Multi-Sited Ethnography: Problems and Possibilities in the Translocation. New York: Routledge.

Mathews, P. (2006) Orchestration: An Anthology of Writings. New York: Routledge.

May, J. and Thrift, N. (eds.) (2003) TimeSpace: Geographies of Temporality. London:

Routledge.

Mayne Reid, T. (1868 [digitised in 2010]) 'Jarocho life', The Galaxy. An Illustrated Magazine of Entertaining Reading, 5 (January-July). Available from: books.google.com.au [ 2 October 2014 ].

Minnegal, M. (2009) 'The time is right: Waiting, reciprocity and sociality', in G. Hage (ed.)

Waiting. Melbourne: Melbourne University Press.

Miranda, A. (2016) 'Journeying with a musical practice: Existential mobility and transnational labour', Mobile Culture Studies: The Journal, 2: 15-30.

Moreno Nájera, A. (2009) Presas del Encanto: Crónicas de Son y Fandango. Estado de México: Programa de Desarrollo Cultural del Sotavento.

Moreno Nájera, A. (2013) Las Pascuas de la Región de los Tuxtlas. Xalapa: Proyectos Culturales de la Región del Sotavento.

Mudarra, A. (1984 [1546]) Tres Libros de Música en Cifra para Vihuela. Barcelona: Instituto Español de Musicología.

Murray Barbour, J. (2004) Tuning and Temperament: A Historical Survey. Mineola, NY: Dover. Narváez, L. (1980 [1538]) Los Seis Libros del Delphín de Música de Cifra para Tañer Vihuela. Geneva: Minkoff.

Nieves, I. (2009) Isidro Nieves. Guitarra de Son [CD]. Mexico: Anona Music.

Noverr, D. A. (2004) 'Popular fiction and the U.S.-Mexico War: Thomas Mayne Reid's The Rifle Rangers (1850) and John Ludlum McConnel's Talbot and Vernon (1850)', Journal of Popular Culture, 35(2): 73-82.

Pareyón, G. (2007) Diccionario Enciclopédico de la Música en México. Mexico City: Universidad Panamericana. 2 vols.

Pérez Monterosas, M. (2003) 'Las redes sociales de la migración emergente de Veracruz a los Estados Unidos', Migraciones Internacionales, 2(1): 136-160.

Pérez Montfort, R. (1992) Tlacotalpan, la Virgen de la Candelaria y los Sones. Mexico City: Fondo de Cultura Económica.

Pérez Montfort, R. (1999) 'Un nacionalismo sin nación aparente: La fabricación de lo "típico" mexicano 1920-1950', Política y Cultura, 12: 177-193.

Pérez Montfort, R. (2003) Estampas de Nacionalismo Popular Mexicano: Diez Ensayos Sobre Cultura Popular y Nacionalismo. Mexico City: CIESAS-CIDHEM.

Pérez Montfort, R. (2007) Expresiones Populares y Estereotipos Culturales en México, Siglos XIX y XX: Diez Ensayos. Mexico City: CIESAS.

Pérez Montfort, R. (2017) 'The fandango as an expression of cultural circulation in Mexico and the Caribbean', in K. Meira Goldberg and A. Pizà (eds.), The Global Reach of the Fandango in Music, Song and Dance: Spaniards, Indians, Africans and Gypsies. Newcastle: Cambridge Scholars.

Peters, G. (2009) The Philosophy of Improvisation. Chicago: University of Chicago Press. Peters, P. (2016) 'Waltzing around the world: Musical mobilities and the aesthetics of adaptation', in K. Hannam , M. Mostafanezhad and J. Rickly , Event Mobilities: Politics, Place and Performance. Abingdon: Routledge.

Plummer, K. (2007) 'Essentialism and constructionism', in G. Ritzer (ed.) The Blackwell Encyclopedia of Sociology. Malden, MA: Blackwell.

Preminger, A. , Brogan, T. V. and Warnke, F. J. (eds.) (1996) New Princeton Encyclopedia of Poetry and Poetics. New York: MJF Books. 
Reckwitz, A. (2002a) 'Toward a theory of social practices: A development in culturalist theorizing', European Journal of Social Theory, 5(2): 243-263.

Reckwitz, A. (2002b) 'The status of the "material" in theories of culture: From "social structure" to "artefacts"', Journal for the Theory of Social Behaviour, 32(2): 195-217.

Robins, R. (2009) 'Waiting for rain in the Goulburn Valley', in G. Hage (ed.) Waiting. Melbourne: Melbourne University Press.

Rodríguez León, F. (1998) Los Instrumentos Musicales del Son Jarocho. Mexico City: Conaculta-INAH.

Sanjek, R. (1990) 'On ethnographic validity', in R. Sanjek (ed.) Fieldnotes: The Makings of Anthropology. Ithaca, NY: Cornell University Press.

Schatzki, T. (1996) Social Practices: A Wittgensteinian Approach to Human Activity and the Social. Cambridge: Cambridge University Press.

Schatzki, T. (2010a) 'Materiality and social life', Nature and Culture, 5(2): 123-149.

Schatzki, T. (2010b) Timespace and Human Activity. Lanham, MD: Lexington.

Schatzki, T. (2011) 'Where the action is (on large social phenomena such as sociotechnical regimes)', SPRG Working Paper 1. Available from: sprg.ac.uk/uploads/schatzki-wp1.pdf [ 20 November 2013 ].

Schatzki, T. , Knorr-Cetina, K. and von Savigny, E. (2005) The Practice Turn in Contemporary Theory. London: Routledge. E-book available from: ebookstore.tandf.co.uk [ 18 March 2013 ].

Sennett, R. (2008) The Craftsman. New Haven: Yale University Press.

Sheehy, D. E. (1979) The Son Jarocho: The History, Style, and Repertoire of a Changing Mexican Musical Tradition. PhD thesis, University of California, Los Angeles.

Shove, E. and Pantzar, M. (2007) 'Recruitment and reproduction: The careers and carriers of digital photography and floorball', Human Affairs, 17: 154-167.

Shove, E. , Pantzar, M. and Watson, M. (2012) The Dynamics of Social Practice: Everyday Life and How it Changes. London: Sage.

Simpson, L. B. (1977) Muchos Méxicos. Mexico City: Fondo de Cultura Económica.

Smith, R. J. and Hetherington, K. (2013) 'Urban rhythms: Mobilities, space and interaction in the contemporary city', Sociological Review, 61: 4-16.

Snow, R. P. and Brissett, D. (1986) Pauses: Explorations in social rhythm, Symbolic Interaction, 9(1): 1-18.

Spinosa, C. (2005) 'Derridian dispersion and Heideggerian articulation', in T. R. Schatzki, K. Knorr-Cetina and E. von Savigny (eds.) The Practice Turn in Contemporary Theory. London: Routledge. E-book available from: ebookstore.tandf.co.uk [ 18 March 2013 ].

Spivak, G. (2006) In Other Worlds: Essays in Cultural Politics. New York: Methuen.

Spring, M. (2001) The Lute in Britain: A History of the Instrument and Its Music. Oxford: Oxford University Press.

Swidler, A. (2005) 'What anchors cultural practices', in T. R. Schatzki, K. Knorr-Cetina and E. von Savigny (eds.) The Practice Turn in Contemporary Theory. London: Routledge. E-book available from: ebookstore.tandf.co.uk [ 18 March 2013 ].

Thrift, N. (1996) Spatial Formations. London: Sage.

Thrift, N. (2008) Non-Representational Theory. London: Routledge.

Toynbee, J. and Dueck, B. (2011) Migrating Music. London: Routledge.

Tsing, A. (2005) Friction: An Ethnography of Global Connection. Princeton, NJ: Princeton University Press.

Tsing, A. (2012) 'Frictions', in G. Ritzer (ed.), The Blackwell Encyclopedia of Sociology. Malden, MA: Blackwell.

Urry, J. (2000) Sociology Beyond Societies: Mobilities for the Twenty-First Century. London: Routledge.

Urry, J. (2003) Global Complexities. Cambridge: Polity Press.

Van Maanen, J. (2011) Tales of the Field: On Writing Ethnography. Chicago: University of Chicago Press.

Vázquez Domínguez, R. (1991) El Son Jarocho: Sus Instrumentos y Sus Versos. Mexico City: Universidad Veracruzana.

Vega Deloya, H. F. (2011) 'La música tradicional mexicana: Entre el folclore, la tradición y la "world music"', Historia Actual Online, 23: 155-169. 
Viesca, V. H. (2004) 'The battle of Los Angeles: The cultural politics of Chicana/o music in the Greater Eastside', American Quarterly, 56(3): 719-739.

Vigneaux, E. (1863 [digitised in 2010]) Souvenirs d'un Prisonnier de Guerre au Mexique, 1854-1855. Paris: Hachette. Available from: books.google.com.au [ 12 September 2015 ].

Wang, S. and Shove, E. (2014) 'How rounders goes around the world', in N. Thrift, A. Tickell , S. Woolgar and W. H. Rupp (eds.) Globalization in Practice. Oxford: Oxford University Press. Whitehead, A. N. (1978) Process and Reality: An Essay in Cosmology. New York: Free Press. Wicker, R. (1997) 'From complex culture to cultural complexity', in P. Werbner and T. Modood (eds.) Debating Cultural Hybridity: Multicultural Identities and the Politics of Anti-Racism. London: Zed Books.

Zerubavel, E. (1976) 'Timetables and scheduling: On the social organisation of time', Sociological Inquiry, 46(2): 87-94.

Zolberg, V. L. (1990) Constructing a Sociology of the Arts. Cambridge: Cambridge University Press. 